Article

\title{
Normalizing HIF-1 $\alpha$ Signaling Improves Cellular Glucose Metabolism and Blocks the Pathological Pathways of Hyperglycemic Damage
}

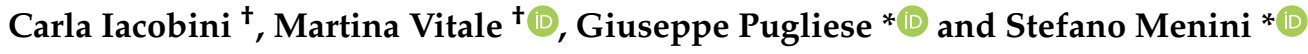 \\ Department of Clinical and Molecular Medicine, "La Sapienza" University, 00189 Rome, Italy; \\ carla.iacobini@uniroma1.it (C.I.); martina.vitale@uniroma1.it (M.V.) \\ * Correspondence: giuseppe.pugliese@uniroma1.it (G.P.); stefano.menini@uniroma1.it (S.M.); \\ Tel.: +39-0633775440 (S.M.) \\ + Carla Iacobini and Martina Vitale contributed equally to this work.
}

Citation: Iacobini, C.; Vitale, M.; Pugliese, G.; Menini, S. Normalizing HIF-1 $\alpha$ Signaling Improves Cellular Glucose Metabolism and Blocks the Pathological Pathways of Hyperglycemic Damage. Biomedicines 2021, 9, 1139. https://doi.org/ 10.3390/biomedicines 9091139

Academic Editor: Chia-Jung Li

Received: 28 July 2021

Accepted: 31 August 2021

Published: 2 September 2021

Publisher's Note: MDPI stays neutral with regard to jurisdictional claims in published maps and institutional affiliations.

Copyright: (c) 2021 by the authors. Licensee MDPI, Basel, Switzerland. This article is an open access article distributed under the terms and conditions of the Creative Commons Attribution (CC BY) license (https:// creativecommons.org/licenses/by/ $4.0 /)$

\begin{abstract}
Intracellular metabolism of excess glucose induces mitochondrial dysfunction and diversion of glycolytic intermediates into branch pathways, leading to cell injury and inflammation. Hyperglycemia-driven overproduction of mitochondrial superoxide was thought to be the initiator of these biochemical changes, but accumulating evidence indicates that mitochondrial superoxide generation is dispensable for diabetic complications development. Here we tested the hypothesis that hypoxia inducible factor (HIF)- $1 \alpha$ and related bioenergetic changes (Warburg effect) play an initiating role in glucotoxicity. By using human endothelial cells and macrophages, we demonstrate that high glucose (HG) induces HIF- $1 \alpha$ activity and a switch from oxidative metabolism to glycolysis and its principal branches. HIF1- $\alpha$ silencing, the carbonyl-trapping and anti-glycating agent L-carnosine, and the glyoxalase- 1 inducer trans-resveratrol reversed HG-induced bioenergetics/biochemical changes and endothelial-monocyte cell inflammation, pointing to methylglyoxal (MGO) as the non-hypoxic stimulus for HIF1- $\alpha$ induction. Consistently, MGO mimicked the effects of HG on HIF-1 $\alpha$ induction and was able to induce a switch from oxidative metabolism to glycolysis. Mechanistically, methylglyoxal causes HIF1- $\alpha$ stabilization by inhibiting prolyl 4-hydroxylase domain 2 enzyme activity through post-translational glycation. These findings introduce a paradigm shift in the pathogenesis and prevention of diabetic complications by identifying HIF- $1 \alpha$ as essential mediator of glucotoxicity, targetable with carbonyl-trapping agents and glyoxalase- 1 inducers.
\end{abstract}

Keywords: carnosine; cellular energetics; diabetes; glycolysis; hyperglycemia; inflammation; methylglyoxal; prolyl 4-hydroxylase 2; trans-resveratrol; Warburg effect

\section{Introduction}

The impact of hyperglycemia on the human vasculature is responsible for most of the morbidity and mortality in both type 1 and type 2 diabetes [1,2]. The injurious effect of hyperglycemia was attributed to biochemical consequences of intracellular metabolism of excess glucose. According to Brownlee's unifying hypothesis, biochemical abnormalities are triggered by mitochondrial superoxide overproduction resulting from hyperglycemiainduced increase in electron donors from the tricarboxylic acid cycle. In turn, superoxide inhibits the glycolytic flux toward oxidative phosphorylation favoring the diversion of intermediates into glycolysis branch pathways, including polyol, hexosamine and advanced glycation endproduct (AGE) pathways [3]. However, at variance with previous reports showing increased superoxide levels [4], recent evidence suggests that superoxide production and mitochondrial function are decreased in the diabetic kidney [5,6]. Accordingly, the role of mitochondrial superoxide as the initial trigger of these ominous changes has been put into question [7,8]. Therefore, the unifying hypothesis of diabetic complications may need an alternative mechanism for instigating two main metabolic changes, 
i.e., (1) glucose-induced inhibition of respiration in the absence of superoxide overproduction; and (2) shifting of glucose flux from oxidative phosphorylation to the glycolytic pathway and its principal branches, ultimately leading to cell injury and inflammation.

Hypoxia-inducible factor- $1 \alpha$ (HIF-1 $\alpha$ ) switches glucose metabolism from oxidative phosphorylation to glycolysis under hypoxic conditions ("Pasteur effect") [9-12] by simultaneously increasing the expression of glycolytic enzymes and restraining mitochondrial function and oxygen consumption [13-15]. Under normoxia conditions, HIF- $1 \alpha$ is rapidly hydroxylated by the oxoglutarate dependent prolyl 4-hydroxylase domain (PHD) 2 enzyme, which leads to HIF- $1 \alpha$ proteosomal degradation [13]. The bulk of research on HIF- $1 \alpha$ concerns crucial aspects of cancer biology [14]; hypoxia, which is a hallmark feature of the tumor microenvironment, promotes protein stability of HIF- $1 \alpha$ subunit by inhibiting the activity of PHDs, as they require oxygen to hydroxylate HIF-1 $\alpha$ [15]. However, even under aerobic conditions, most cancer cells tend to favor metabolism via aerobic glycolysis rather than through oxidative phosphorylation, a phenomenon termed "Warburg effect" [12-15]. In addition, metabolic changes resembling the Warburg effect play a role in inflammation, as increased HIF- $1 \alpha$ signaling, reduction of glucose oxidation and switching to aerobic glycolysis are required for interleukin $1 \beta$ (IL-1 $\beta)$ mRNA induction in stimulated macrophages [16-18] and for myeloid cell-mediated inflammation [17]. Consistently, HIF$1 \alpha$-deficient macrophages show a defective response to lipopolysaccharide (LPS) (i.e., loss of inflammatory capacity) [17]. Interestingly, hyperglycemia has also been reported to induce HIF- $1 \alpha$ upregulation in renal and vascular cells $[19,20]$. Indeed, HIF- $1 \alpha$ has been involved in vascular complications mainly because of the role of hypoxia in vascular injury and repair [21].

This study aimed at investigating whether high glucose (HG) conditions induce HIF$1 \alpha$ activity and related cellular energetic changes (i.e., Warburg effect), which may serve as initial mediators of glucose toxicity by activating the alternative pathways of glucose metabolism involved in hyperglycemia-induced vascular damage.

\section{Material and Methods}

This study was designed to test the hypothesis that HIF- $1 \alpha$ plays an initiating role in HG-induced endothelial cell and macrophage activation by initiating a metabolic shift towards glycolysis and shunting of glucose into glycolysis side-branches.

\subsection{Cell Culture}

Human umbilical vascular endothelial cells (HUVEC), order number C-12203/C12253, lot number 439Z032, were purchased from PromoCell (Heidelberg, Germany), human coronary artery endothelial cells (HCAEC), EGM-2MV, batch number 0000396592, from Lonza Group (Milan, Italy), and the monocyte/macrophage cell line U937 from the European Collection of Authenticated Cell Cultures (ECACC, Salisbury, UK, SOP ECACC / 079). Mycoplasma contamination in cell cultures was regularly (monthly) tested by Real Time PCR (RT-PCR) MycoSPY Kit (Biontex, Munchen, Germany). Cells were grown at $37{ }^{\circ} \mathrm{C}$ in $95 \%$ air- $5 \% \mathrm{CO}_{2}$ in $100-\mathrm{mm}^{2}$ cell culture dishes. Cells were fed every 3-4 days with the recommended medium EGM-2 MV BulletKit ${ }^{\mathrm{TM}}$ Medium (Lonza Group) for HUVEC and HCAEC, and RPMI medium (Thermo Fisher Scientific, Waltham, MA, USA) supplemented with $10 \%$ fetal bovine serum, penicillin $(100 \mathrm{U} / \mathrm{mL})$ and streptomycin $(100 \mathrm{mg} / \mathrm{mL})$ for U937 cells.

\subsection{Cell Treatments}

HUVEC, HCAEC and U937 cells were grown under normal glucose (NG, $5.5 \mathrm{mM}$ ) and HG (10, 20 and $30 \mathrm{mM}$ ) conditions for different times (from 0 to $72 \mathrm{~h}$ ), (1) in the presence or absence of L-Carnosine (Car, $20 \mathrm{mM}$, Sigma-Aldrich, St. Louis, MO, USA), an endogenous dipeptide shown to protect against several oxidative-based diseases by trapping carbonyl compounds [22,23], including the toxic $\alpha$-oxoaldehyde and glycolysis side product methyl glyoxal (MGO) [24,25], (2) with or without trans-resveratrol (Res, $10 \mu \mathrm{M}$, Sigma-Aldrich), 
a prototype inducer of the glyoxalase-1 (GLO1) enzyme that detoxifies $\alpha$-oxoaldehydes, including MGO [26], or (3) in cells silenced or not for HIF-1 $\alpha$. Mannitol was used as osmotic control for HG effects on HIF-1 $\alpha$ activity and proinflammatory activation of endothelial cells and macrophages (Supplementary Figure S1). In U937 cells, the effects of HG were analysed upon LPS $(10 \mathrm{ng} / \mathrm{mL})$ stimulation. HUVEC and U937 cells were also incubated with MGO $(0.2 \mathrm{mM}, 48 \mathrm{~h})$. Whole cell and nuclear proteins were extracted using the Whole Cell and Nuclear Extraction Kits (Abcam, Cambridge, UK), respectively.

\section{3. $m R N A$ and Nuclear Protein Levels of HIF-1 $\alpha$}

The mRNA and nuclear protein levels of HIF- $1 \alpha$ were assessed by RT-PCR using inventoried TaqMan gene expression assays (Applied Biosystems, Carlsbad, CA, USA, Table 1), and Western blot and immunofluorescence (IF), using specific anti-HIF- $1 \alpha$ antibodies (Table 2). IF images were acquired using a 40x/N.A. 1.3 oil objective on a Zeiss Axiovert $200 \mathrm{M}$ fluorescence microscope equipped with an Axiocam 503 color camera, controlled with ZEN (blue edition) software (Zeiss, Milan, Italy).

Table 1. TaqMan Gene Expression assays.

\begin{tabular}{cc}
\hline Target & Assay \\
\hline HIF-1 $\alpha$ & Hs00153153_m1 (\#4331182) \\
$V C A M-1$ & Hs01003372_m1 (\#4331182) \\
$M C P-1 / C C L 2$ & Hs00234140_m1 (\#4331182) \\
$I L-1 \beta$ & Hs0155410_m1 (\#4331182) \\
PGC-1 $\alpha$ & Hs00173304_m1 (\#4331182) \\
PHD2 $/ E G L N 1 B$-actin & Hs00254392_m1 (\#4331182) \\
B-actin & Hs99999903_m1 (\#4331182) \\
\hline
\end{tabular}

HIF- $1 \alpha$ = hypoxia inducible factor $1 \alpha ; V C A M-1$ = vascular cell adhesion molecule $1 ; M C P-1 / C C L 2$ = monocyte chemoattractant protein $1 / C-C$ motif chemokine ligand $2 ; I L-1 \beta=$ interleukin $1 \beta ; P G C-1 \alpha=$ peroxisome proliferator-activated receptor gamma coactivator $1 \alpha ; P H D 2 / E G L N 1=$ prolyl hydroxylase domain-containing protein 2/egl-9 family hypoxia inducible factor 1.

\subsection{General Methods for $m R N A$ and Protein Expression Analysis}

RNA was isolated using the RNeasy Plus Mini Kit (Qiagen, Milan, Italy) and RNA reverse transcription was performed with High Capacity cDNA Reverse Transcription kit (Thermo Fisher Scientific). The StepOne ${ }^{\mathrm{TM}}$ Real Time PCR System (Thermo Fisher Scientific) was used to quantify the relative gene expression levels and analyse the data. Gene expressions were calculated using the $\Delta \Delta \mathrm{Ct}$ method and were normalized to control ( $\beta$-actin expression). Western blot experiments were performed as per manufacturer's instructions. Briefly, protein samples were subjected to SDS-PAGE and transferred to PVDF membranes. Skin milk (5\%) was used as blocking agent, while skin milk or BSA (5\%) were used as incubation solutions depending on the antibodies and relative manufacturers' instructions. Primary antibodies were incubated overnight at $4{ }^{\circ} \mathrm{C}$ and secondary antibodies at RT for $1 \mathrm{~h}$. Blots were developed by enhanced chemiluminescence using Clarity or Clarity Max ECL substrates (Bio-Rad Laboratories, Milan, Italy). The chemiluminescent signal was detected and quantified by ChemiDoc XRS system (Bio-Rad Laboratories).

\subsection{HIF-1 $\alpha$ Activity}

HIF- $1 \alpha$ activity was assessed by luciferase assay using the Cignal HIF- $1 \alpha$ Reporter (luc) Kit (Qiagen). Briefly, cells were transiently transfected with an inducible transcription factor-responsive firefly luciferase reporter using Attractene Transfection Reagent (Qiagen), according to the manufacturer's instructions. The luminescence was measured using Dual-Luciferase Reporter Assay Kit (Promega, Milan, Italy). 
Table 2. Antibodies used in Western blot and IF studies.

\begin{tabular}{|c|c|c|c|}
\hline Target & Antibody & Catalog Nr. & Supplier \\
\hline \multicolumn{4}{|l|}{ Primary } \\
\hline HIF-1 $\alpha(\mathrm{WB})$ & Rabbit polyclonal & \#3716 & Cell Signaling Technology, Leiden, The Netherlands \\
\hline $\mathrm{HIF}-1 \alpha(\mathrm{IF})$ & Rabbit monoclonal & ab51608 & Abcam, Cambridge, UK \\
\hline Pro-OH HIF-1 $\alpha(\mathrm{WB})$ & Rabbit monoclonal & 3434 & Cell Signaling Technology, Danvers, MA, USA \\
\hline PHD2/EGLN1 (IP-WB) & Rabbit polyclonal & NB100-137 & Novus Biologicals, Centennials, CO, USA \\
\hline HK2 (WB) & Mouse monoclonal & ab104836 & Abcam, Cambridge, UK \\
\hline PKM2 (WB) & Rabbit polyclonal & \#3198 & Cell Signaling Technology, Danvers, MA, USA \\
\hline LDHA (WB) & Rabbit polyclonal & 19987-1-AP & Proteintech, Manchester, UK \\
\hline PDK1 (WB) & Rabbit monoclonal & \#3820 & Cell Signaling Technology, Danvers, MA, USA \\
\hline MT-CO1 (IF) & $\begin{array}{c}\text { Mouse monoclonal } \\
\text { conjugated to Alexa } \\
\text { Fluor }^{\circledR} 488\end{array}$ & Ab154477 & Abcam, Cambridge, UK \\
\hline MGO (IP-WB) & Mouse monoclonal & NBP-2 59368 & Novus Biologicals, Centennials, CO, USA \\
\hline IgG2 Isotype control (IP) & Mouse monoclonal & ab18415 & Abcam, Cambridge, UK \\
\hline IgG Isotype control (IP) & Rabbit monoclonal & Ab172730 & Abcam, Cambridge, UK \\
\hline B-actin & Mouse monoclonal & A5441 & Sigma Aldrich, St. Louis, MO, USA \\
\hline Histone H3 (WB) & Rabbit polyclonal & ab1791 & Abcam, Cambridge, UK \\
\hline \multicolumn{4}{|l|}{ Secondary } \\
\hline $\begin{array}{c}\text { HIF-1 } \alpha \text { (WB), Pro-OH HIF-1 } \alpha \text {, } \\
\text { PHD2/EGLN1, PKM2, LDHA, } \\
\text { PDK1 }\end{array}$ & $\begin{array}{l}\text { HRP-conjugated goat } \\
\text { anti-rabbit }\end{array}$ & P0448 & Agilent/Dako, Santa Clara, CA, USA \\
\hline B-actin, HK2, MGO & $\begin{array}{l}\text { HRP-conjugated goat } \\
\text { anti-mouse }\end{array}$ & P0447 & Agilent/Dako, Santa Clara, CA, USA \\
\hline HIF-1 $\alpha(\mathrm{IF})$ & $\begin{array}{l}\text { Alexa Fluor }^{\circledR} \text { Plus } 488 \\
\text { goat anti-rabbit IgG }\end{array}$ & A-32731 & Thermo Fisher Scientific, Waltham, MA, USA \\
\hline
\end{tabular}

HIF- $1 \alpha=$ hypoxia inducible factor $1 \alpha$; WB = Western blot; IF = immunofluorescence; Pro-OH HIF- $1 \alpha=$ proline-hydroxylated hypoxiainducible factor $1 \alpha$; PHD2/EGLN1 = prolyl hydroxylase domain-containing protein 2/egl-9 family hypoxia inducible factor 1; HK2 = hexokinase 2; PKM2 = pyruvate kinase isozymes M2; LDHA = lactate dehydrogenase A; PDK1 = pyruvate dehydrogenase kinase 1; MT$\mathrm{CO} 1$ = mitochondrially encoded cytochrome $\mathrm{C}$ oxidase $\mathrm{I} ; \mathrm{MGO}=$ methylglyoxal; $\mathrm{IP}=$ immunoprecipitation.

\subsection{HIF-1 $\alpha$ Silencing}

HIF-1 $\alpha$ silencing (si-HIF-1 $\alpha$ ) was performed by Silencer ${ }^{\circledR}$ Select \& Validated small interfering RNA (Thermo Fisher Scientific) using the assay ID s6539 and a non-targeting negative control siRNA. Cells were transfected with Lipofectamine RNAiMAX Reagent (Invitrogen, Carlsbad, CA, USA).

\subsection{Endothelial Cell and Macrophage Activation}

The mRNA expression of vascular cell adhesion molecule 1 (VCAM-1) and monocyte chemoattractant protein-1/C-C motif chemokine ligand 2 (MCP-1/CCL2) in HUVEC, and $I L-1 \beta$ mRNA in U937 cells were assessed by RT-PCR (Table 1). The release of $I L-1 \beta$ and tumor necrosis factor (TNF)- $\alpha$ into the medium of U937 cells was assessed by using the Human IL-1 $\beta /$ IL-1F2 and TNF- $\alpha$ Quantikine ELISA kits from R\&D Systems (Milan, Italy).

\subsection{MGO-Mediated Post-Translational Modification and Hydroxylation Activity of PHD2}

PHD2 mRNA (Table 1) and protein (Table 2) levels were assessed by RT-PCR and Western blot, respectively. To investigate the effect of MGO on PHD2 activity, proteasome activity was inhibited with $10 \mu \mathrm{M}$ MG132 (Selleckchem Chemicals, Houston, TX, USA) for $6 \mathrm{~h}$. Cytosolic and nuclear proteins were extracted using the Extraction Kits (Abcam) and analysed by Western blot for prolyl-hydroxylated (Pro-OH) HIF- $1 \alpha$ and nuclear HIF- $1 \alpha$, respectively (Table 2). To explore MGO-mediated post-translational modification of PHD2, MGO protein adducts, PHD2 and mouse IgG immunoprecipitations (IP) were performed using the Pierce Crosslink Magnetic IP/Co-IP kit (Thermo Fischer Scientific, Waltham, MA, USA) according to manufacturer instruction (Table 2). Proteins were extracted in Pierce IP Lysis Buffer (Thermo Fischer Scientific). In brief, $25 \mu \mathrm{L}$ of Protein A/G magnetic beads 
crosslinked to $5 \mu \mathrm{g}$ of anti-PHD2/EGLN1, anti-MGO-modified proteins, or IgG2 Isotype control antibodies were incubated with $500 \mu \mathrm{g}$ of cell lysate for $1 \mathrm{~h}$ at room temperature. Then, the beads were washed to remove non-bound material and a low $\mathrm{pH}$ elution buffer was used to dissociate bound antigen from the antibody-crosslinked beads. The IP proteins were analysed by Western blot (Table 2).

\subsection{Expression Levels of Glycolytic Enzymes and Markers of Aerobic Metabolism}

To investigate the HIF-1 $\alpha$-mediated increase in glycolysis and suppression of mitochondrial respiration and biogenesis, the protein levels of known targets of HIF-1 $\alpha$, including the glycolytic enzymes hexokinase 2 (HK2), pyruvate kinase M2 (PKM2), lactate dehydrogenase A (LDHA) $[12,14,16,27,28]$, and pyruvate dehydrogenase kinase 1 (PDK1), a serine/threonine kinase that inhibits mitochondrial respiration by inactivating pyruvate dehydrogenase [15], were evaluated by Western blot (Table 2). Aerobic metabolism was assessed by measuring mRNA expression of another HIF-1 $\alpha$ target, peroxisome proliferator-activated receptor gamma coactivator $1-\alpha(P G C-1 \alpha)$ (Table 1$)$, which is a positive regulator of mitochondrial biogenesis and function [29]. Mitochondrial function was also evaluated by IF analysis of mitochondrially encoded cytochrome c oxidase subunit 1 (MT-CO1) of respiratory Complex IV (Table 2), a key enzyme in aerobic metabolism. IF images were acquired as detailed above.

\subsection{Monitoring of Mitochondrial Respiration and Glycolytic Flux}

The shift from oxidative phosphorylation to aerobic glycolysis was analysed by evaluating cellular oxygen consumption and glycolysis in living cells using Oxygen consumption/Glycolysis Dual Assay Kit (Cayman Chemical, Ann Arbor, MI, USA). Briefly, the signal from a phosphorescent oxygen probe (MitoXpress ${ }^{\circledR}$ - Xtra) and the concentration of lactate released into the culture medium were evaluated and quantified by means of a multimode microplate reader (Varioskan Lux, Thermo Fischer Scientific).

\subsection{Alternative Pathways of Glucose Metabolism and Superoxide Anion Inhibition}

The flux of glucose through the polyol and hexosamine pathways was assessed using the D-Sorbitol Assay Colorimetric Kit (Abcam) and the Glutamine-Fructose-6-Phosphate Transaminase 1 (GFPT1) kit (Aviva Systems Biology, San Diego, CA, USA), respectively. Intracellular formation of AGEs was measured by the OxiSelect ${ }^{\mathrm{TM}}$ Advanced Glycation EndProduct Competitive ELISA Kit (Cell Biolabs, San Diego, CA, USA). Polyethylene glycolsuperoxide dismutase (PEG-SOD, $50 \mathrm{U} / \mathrm{mL}$, Sigma-Aldrich), a cell permeable analogue of SOD, was used to quench superoxide.

\subsection{Statistical Analysis}

The numbers of biological (i.e., independent experiments) or technical (used to ensure the reliability of single values) replicates are reported in figure legends. Results are expressed as mean \pm SEM and fold or \% change vs. controls. For comparisons between two groups, unpaired Student's t-tests with no assumption of equal variance were used. For comparisons of more than two groups, one-way ANOVA followed by the Tukey's posttest for multiple comparisons or two-way ANOVA followed by the Bonferroni post-test were used, as appropriate. A $p$-value $<0.05$ was considered significant. All statistical tests were performed on raw data using GraphPad Prism version 5.00 for Windows (GraphPad Software, San Diego, CA, USA).

\section{Results}

\subsection{HIF-1 $\alpha$ Induction and Cell Activation by High Glucose}

HG (20 mM) induced nuclear translocation of HIF-1 $\alpha$ in both HUVEC (Figure 1A,B) and LPS-stimulated (10 ng/mL) U937 macrophage cell line (Figure 1C) at $48 \mathrm{~h}$. Similar results to those in HUVEC were obtained in HCAEC (Figure 1D). In HUVEC, glucose induced HIF- $1 \alpha$ nuclear translocation in a dose-dependent manner, ranging from $90 \%$ at 
$10 \mathrm{mM}$ to $\sim 9$-fold at $30 \mathrm{mM}$ after $48 \mathrm{~h}$, and a weak increase in HIF-1 $\alpha \mathrm{mRNA}$ expression (Figure 1E), which reached significance only for the highest concentration $(30 \mathrm{mM})$ at the longer time point of $72 \mathrm{~h}$ (Figure $1 \mathrm{~F}$ ). A weak and late effect on HIF-1 $\alpha$ mRNA levels was also observed in LPS-stimulated U937 cells (Figure 1G), confirming that glucoseinduced HIF-1 $\alpha$ nuclear translocation can be accounted for by protein changes, not by transcriptional regulation. As assessed by luciferase gene reporter assay, HIF-1 $\alpha$ activity was increased by 66\% in HUVEC (Figure 2A) and >2-fold in LPS-stimulated U937 cells (Figure 2B) after $48 \mathrm{~h}$ incubation in HG.
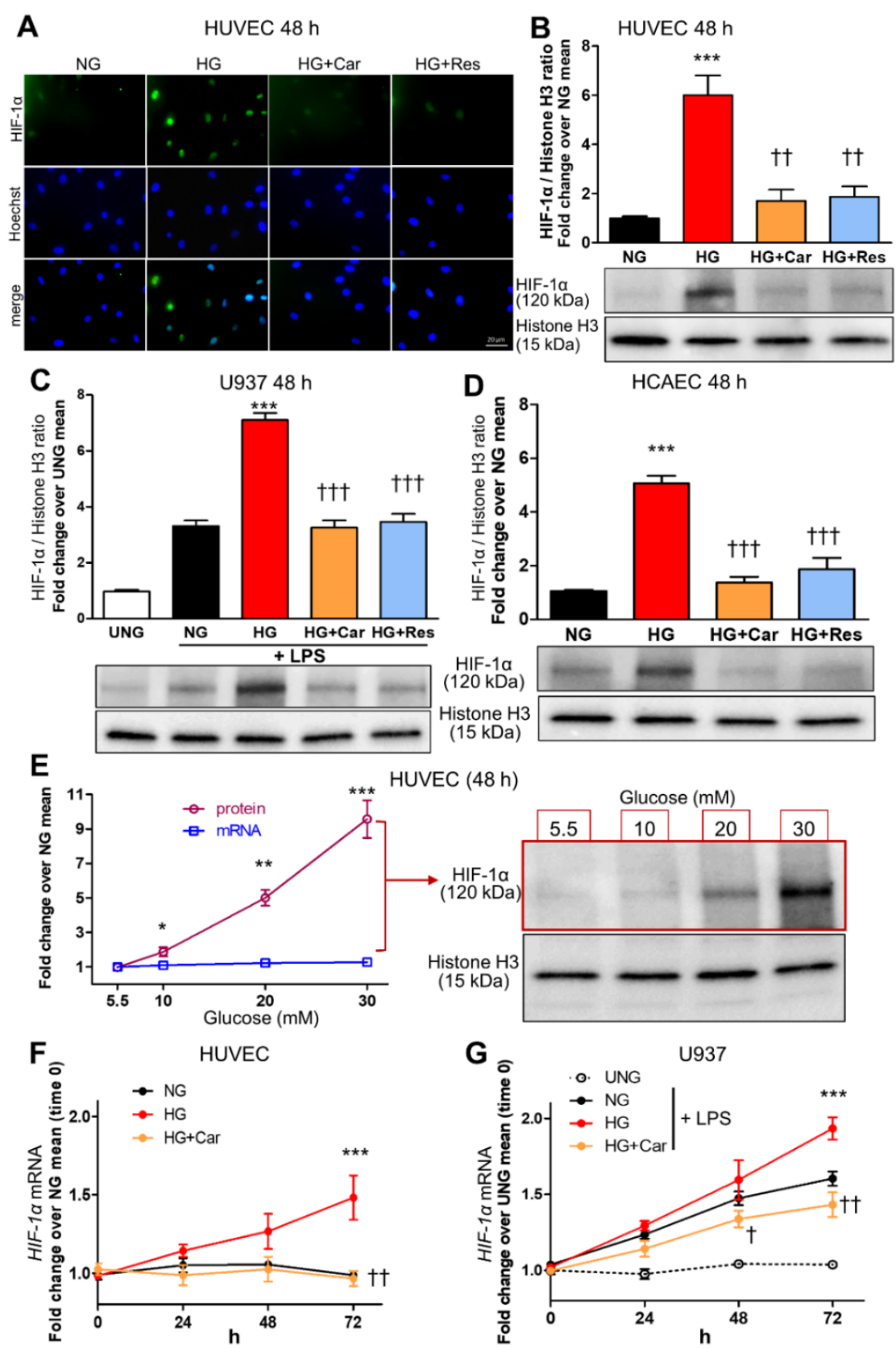

Figure 1. HG increases HIF-1 $\alpha$ nuclear translocation in endothelial cells and LPS-stimulated macrophages. Representative IF ((A), scale bar $20 \mu \mathrm{m})$ and Western blot (B) for nuclear HIF-1 $\alpha$ in HUVEC exposed to HG $(20 \mathrm{mM})$ vs. NG $(5.5 \mathrm{mM})$ for $48 \mathrm{~h}$, with or without the carbonyl trapping agent $\operatorname{Car}(20 \mathrm{mM})$ or the glyoxalase inducer Res $(10 \mu \mathrm{M})$, and relative band densitometry analysis from three separate experiments. Western blot analysis for nuclear HIF-1 $\alpha$ in U937 cells stimulated (or not, UNG = untreated NG) with LPS (10 ng/mL) (C), and HCAEC (D), after $48 \mathrm{~h}$ incubation with 
HG vs. NG with or without Car or Res, and relative band densitometry analysis from three separate experiments. Dose response curve (E) of nuclear HIF- $1 \alpha$ protein levels $(n=3$ separate experiments per condition, black line) and mRNA HIF- $1 \alpha$ expression $(n=5$ wells in duplicate per condition, blue line) in HUVEC exposed to varying concentrations of glucose ranging from 5,5 $\mathrm{mM}$ to $30 \mathrm{mM}$ for $48 \mathrm{~h}$, and representative Western blot image (right side of panel (E)). Time course of HIF-1 $\alpha$ mRNA expression in HUVEC (F) and U937 cells stimulated (or not, UNG) with LPS (G), exposed to HG vs. NG for different times ranging from 0 to $72 \mathrm{~h}$, with or without Car; $n=5$ wells in duplicate per time point per condition. Bars represent mean \pm SEM. Post hoc multiple comparison: ${ }^{* * *} p<0.001$, ** $p<0.01$ or * $p<0.05$ vs. NG; +†+ $p<0.001$, +† $p<0.01$ or $+p<0.05$ vs. HG.
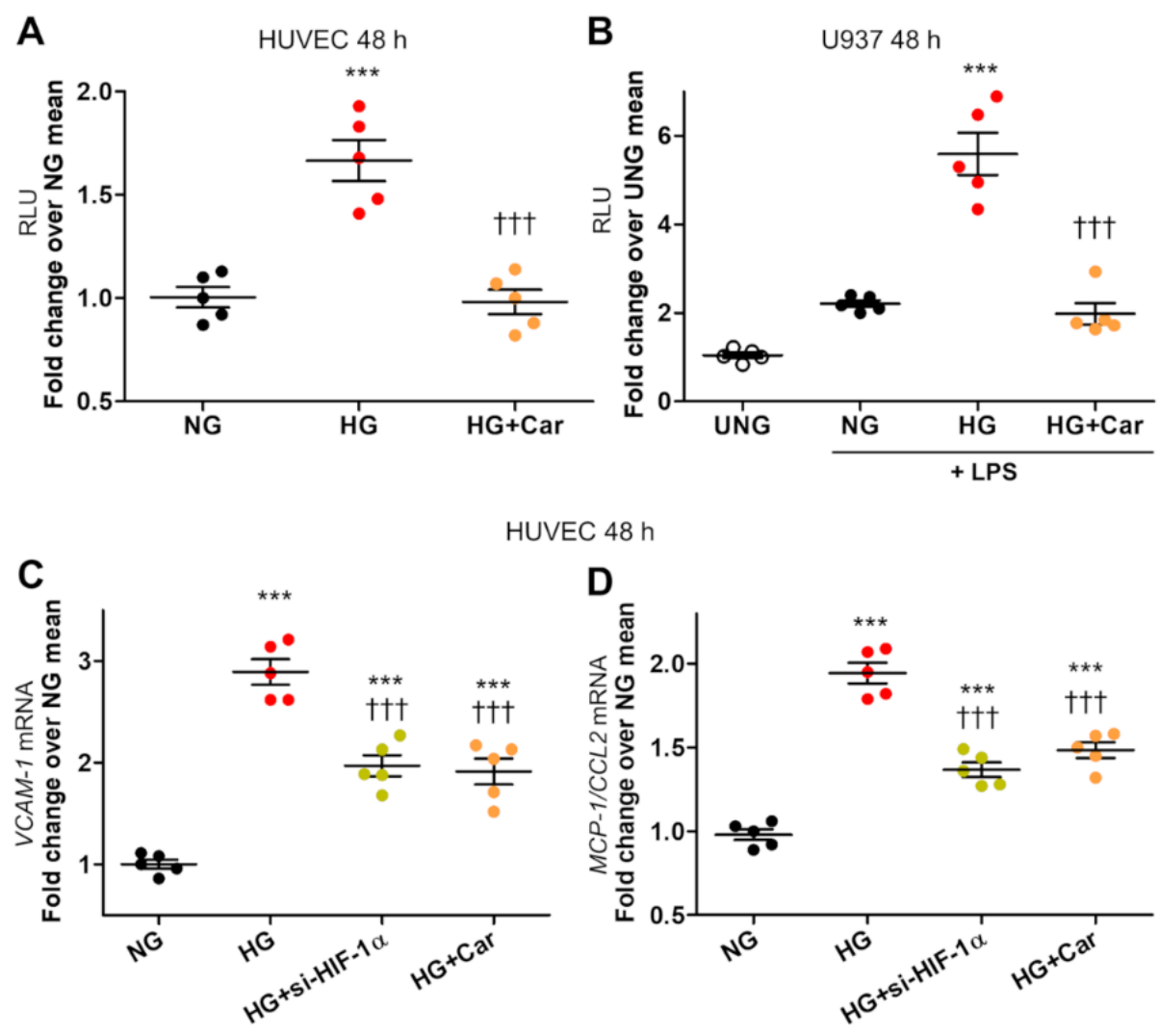

U937 $48 \mathrm{~h}$
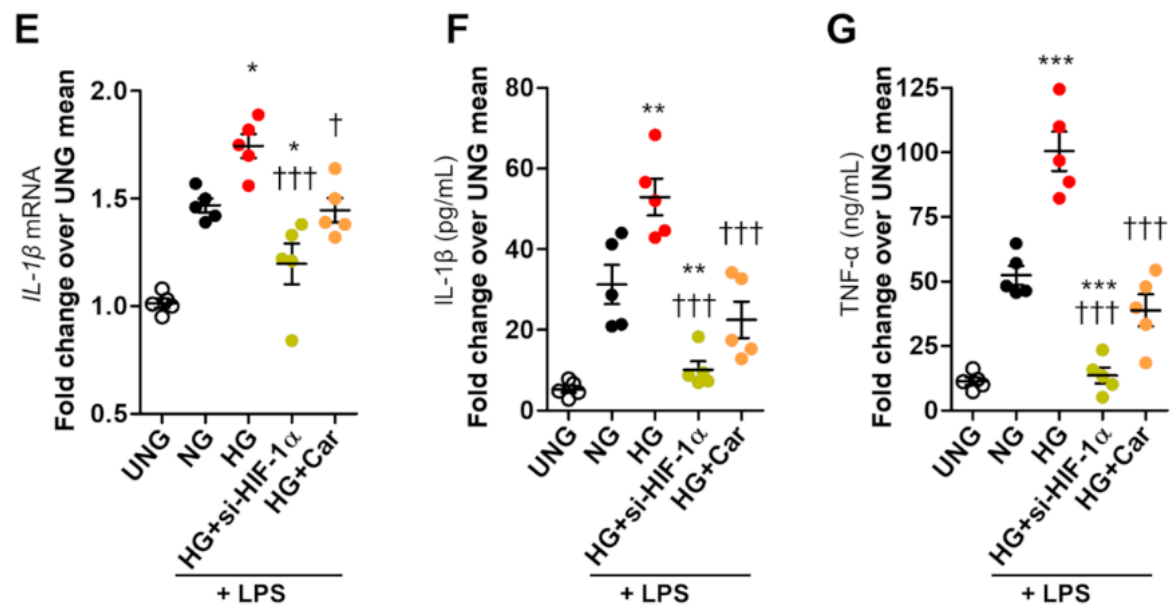

Figure 2. HG-induced HIF-1 $\alpha$ activity is associated with proinflammatory activation in endothelial cells and LPS-stimulated macrophages. HIF-1 activity, as assessed by dual-luciferase gene reporter 
assay, in HUVEC (A), and in U937 macrophages stimulated (or not, UNG = untreated normal glucose) with LPS (10 ng/mL) (B), after $48 \mathrm{~h}$ incubation with HG $(20 \mathrm{mM})$ vs. NG $(5.5 \mathrm{mM})$, with or without Car (20 mM); $n=5$ wells in duplicate per condition. VCAM-1 (C) and MCP-1/CCL2 (D) mRNA levels in HUVEC, and $I L-1 \beta$ mRNA levels in U937 macrophages stimulated (or not, UNG) with LPS (E), exposed to HG vs. NG for $48 \mathrm{~h}$, silenced for HIF-1 $\alpha$ (si-HIF-1 $\alpha$ ), or treated with Car; $n=5$ wells in duplicate per condition. $I L-1 \beta(\mathbf{F})$ and TNF- $\alpha(\mathbf{G})$ protein levels in the culture medium of U937 cells stimulated (or not, UNG) with LPS after $48 \mathrm{~h}$ incubation with HG vs. NG, silenced for HIF- $1 \alpha$, or treated with Car; $n=5$ wells in duplicate per condition. Each dot represents the mean of two individual technical replicate and bars represent mean \pm SEM. Post hoc multiple comparison: *** $p<0.001,{ }^{* *} p<0.01$ or $*<0.05$ vs. NG; +†+ $p<0.001$ or $+p<0.05$ vs. HG.

HIF-1 $\alpha$ nuclear translocation and activity were accompanied by upregulation of VCAM-1 (2.9-fold, Figure 2C) and MCP-1/CCL2) (2-fold, Figure 2D) in HUVEC. In U937 cells, HIF- $1 \alpha$ induction by HG was associated with increased mRNA levels of $I L-1 \beta(+50 \%$, Figure $2 \mathrm{E}$ ) and secretion of $I L-1 \beta$ ( $+84 \%$, Figure $2 \mathrm{~F}$ ) and TNF- $\alpha$ (2-fold, Figure $2 \mathrm{G})$. si-HIF- $1 \alpha$ significantly reduced $\mathrm{HG}$-induced proinflammatory cell activation, as it reduced the mRNA expressions of VCAM-1 (-52\%, Figure 2C) and MCP-1 (-60\%, Figure 2D) in HUVEC and reversed upregulation of $I L-1 \beta$ (Figure $2 \mathrm{E}$ ) and secretion of $I L-1 \beta$ (Figure $2 \mathrm{~F}$ ) and TNF- $\alpha$ (Figure $2 \mathrm{G}$ ) in U937 cells. Consistent with a critical role of HIF- $1 \alpha$ signalling in macrophage activation (16-18), in addition to reversing the effect of HG, si-HIF-1 $\alpha$ was even able to prevent LPS-dependent secretion of $I L-1 \beta$ (Figure 2F) and TNF- $\alpha$ (Figure 2G) in U937 cells.

\section{2. $\alpha$-Oxoaldehydes as Mediators of Glucose-Induced HIF-1 $\alpha$ Induction}

Car inhibited HG-induced nuclear translocation of HIF-1 $\alpha$ in HUVEC (Figure 1A,B), U937 cells (Figure 1C), and HCAEC (Figure 1D). Car also inhibited HG-induced HIF-1 $\alpha$ activity in HUVEC and U937 cells (Figure 3A,B) and significantly reduced the mRNA levels of VCAM-1 (-48\%) (Figure 2C) and MCP-1 (-44\%) (Figure 2D) compared with untreated HUVEC. Finally, Car normalized the $I L-1 \beta$ (Figure $2 \mathrm{E}$ ) and $I L-1 \beta$ (Figure $2 \mathrm{~F}$ ) mRNA levels and TNF- $\alpha$ (Figure 2G) secretion into the culture medium of U937 cells. Similar effects in preventing HIF-1 $\alpha$ nuclear translocation by HG were obtained by treating HUVEC (Figure 1A,B), U937 cells (Figure 1C), and HCAEC (Figure 1D) with Res. Consistently, treatment with MGO $(200 \mu \mathrm{M})$ in NG $(5.5 \mathrm{mM})$ conditions induced HIF-1 $\alpha$ nuclear translocation in both HUVEC (Figure 3A) and U937 cells (Figure 3B) by 6-fold and 2-fold, respectively, an effect that was efficiently inhibited by the carbonyl trapping agent Car (Figure 3A,B).

To identify the mechanism involved in HIF- $1 \alpha$ stabilization, we investigated whether MGO could affect mRNA and protein expression levels of PHD2, but obtained negative results (Figure 3C,D).

\subsection{Inhibition of PHD2 Hydroxylation Activity by Post-Translational Glycation Mediated by $M G O$}

We next investigated whether MGO could modify PHD2 post-translationally, thus affecting its hydroxylase activity. For this purpose, it was examined whether MGO-modified PHD2 could be detected in MGO-treated HUVEC. IP of MGO-treated cell extracts using a specific antibody for MGO modified proteins followed by PHD2 immunoblot analysis revealed a low but detectable basal level of MGO-modified PHD2 in HUVEC that was enhanced upon MGO treatment (Figure 4A).

IP of MGO-treated cell extracts using anti-PHD2 followed by immunoblot analysis of MGO protein adducts confirmed an enrichment of MGO-modified PHD2 in HUVEC cells treated with this glycolytic side product (Figure 4B). 

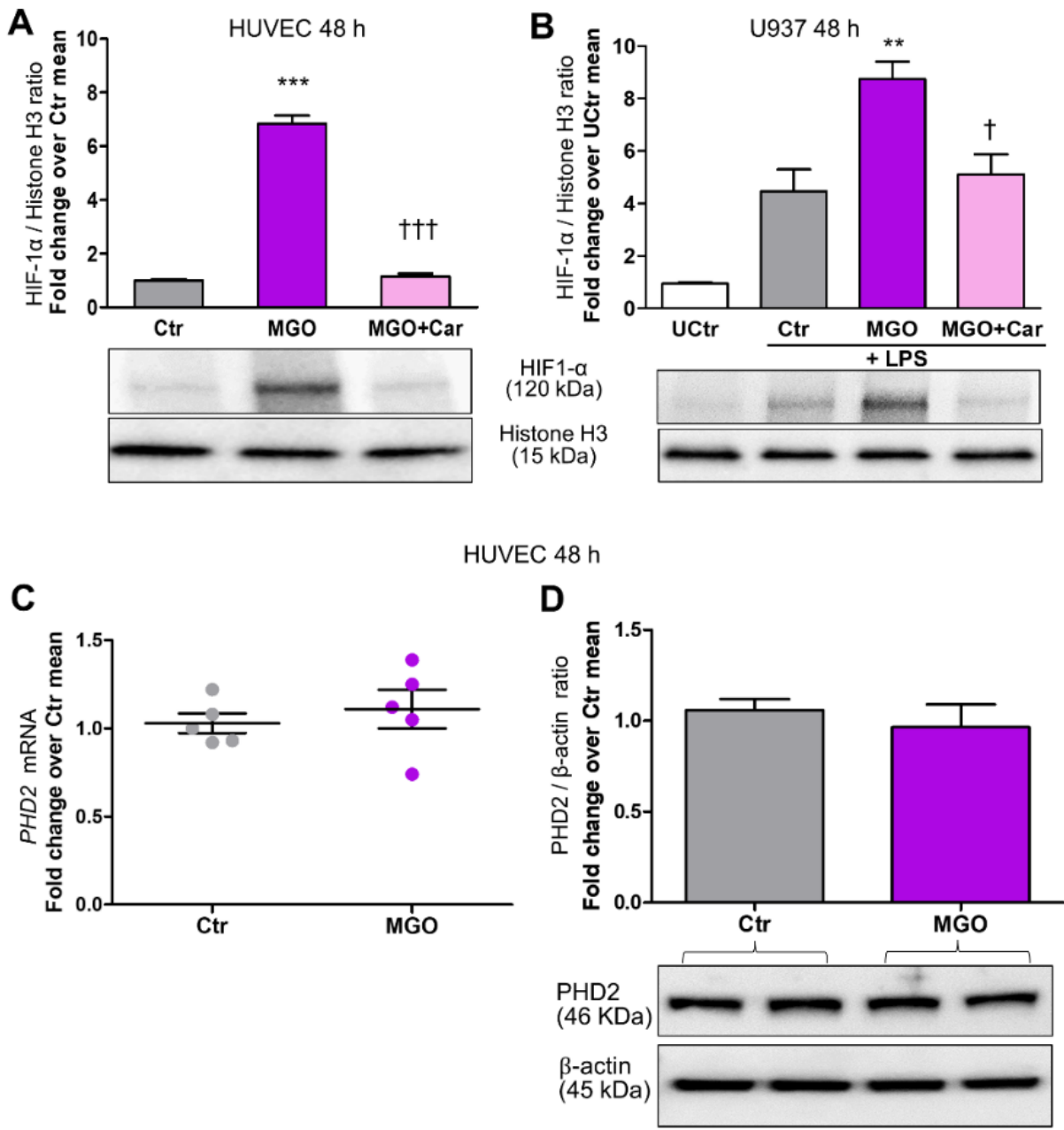

Figure 3. The glycolytic side-product MGO increases HIF- $1 \alpha$ nuclear translocation in endothelial cells and LPS-stimulated macrophages but does not affect mRNA and protein levels of PHD2. Western blot analysis for HIF-1 $\alpha$ in nuclear extracts from HUVEC (A) and U937 cells stimulated (or not, UCtr $=$ untreated control) with LPS $(10 \mathrm{ng} / \mathrm{mL})(\mathbf{B})$, treated or untreated $(\mathrm{Ctr})$ with the reactive dicarbonyl compound MGO $(200 \mu \mathrm{M})$ for $48 \mathrm{~h}$, in the presence or absence of the carbonyl trapping agent Car $(20 \mathrm{mM})$, and relative band densitometry analysis from three separate experiments. PHD2 mRNA $((\mathbf{C}), n=5)$ and protein levels in total extracts (D), from HUVEC treated or untreated (Ctr) with MGO $(200 \mu \mathrm{M})$ for $48 \mathrm{~h}$, and relative band densitometry analysis from three separate experiments. Each dot in $(\mathbf{C})$ represents the mean of two individual technical replicate. Bars represent mean \pm SEM. Post hoc multiple comparison: ${ }^{* *} p<0.001$ or ${ }^{* *} p<0.01$ vs. Ctr; $++\dagger p<0.001$ or $+p<0.05$ vs. MGO.

To evaluate the magnitude of the effect of MGO on PHD2 activity, HUVEC cultured in NG were treated with MG132 to inhibit the proteasome activity and consequent degradation of (Pro-OH) HIF-1 $\alpha$ (Figure 4C). Then, cytosolic extracts were tested by Western blot using an antibody specifically directed to (Pro-OH) HIF- $1 \alpha$, whereas the nuclear extracts were analysed using an anti-HIF- $1 \alpha$ antibody that does not detect the Pro-OH form of HIF-1 $\alpha$. As expected, proteasome inhibition caused a build-up of (Pro-OH) HIF-1 $\alpha$ in the cytosol of HUVEC. Conversely, proteasome inhibition in MGO-treated cells did not result in an accumulation of (Pro-OH) HIF- $1 \alpha$, indicating the suppression of PHD2 activity by MGO (Figure 4D). Western blot of nuclear extracts confirmed increased nuclear translocation of HIF- $1 \alpha$ in cells treated with MGO (Figure 4E). Treatment with Car significantly restored PHD activity and reduced HIF- $1 \alpha$ nuclear localization (Figure 4D,E) induced by MGO. 
A

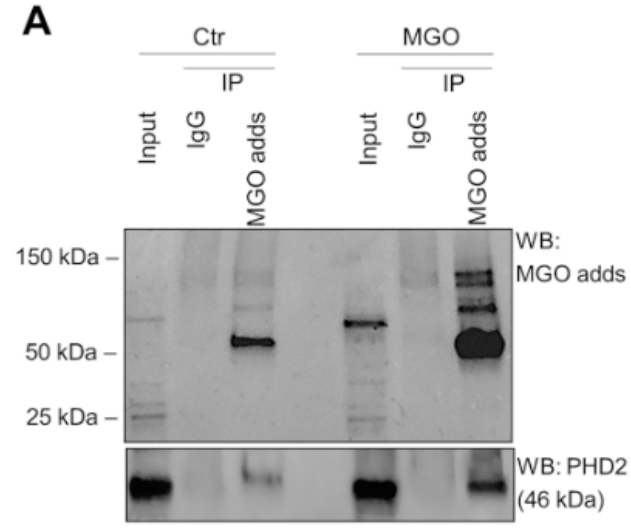

C

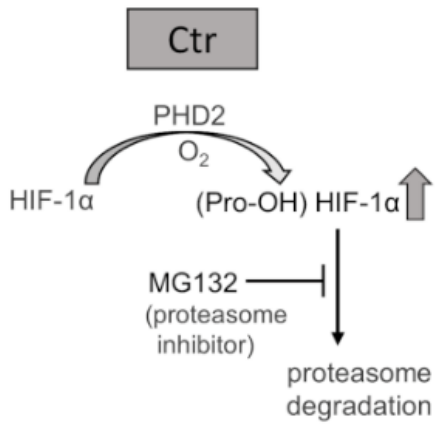

B

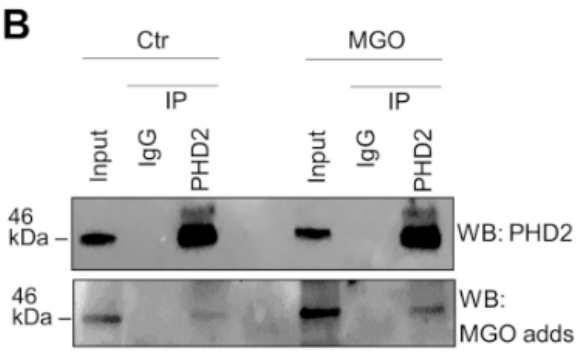

\section{HUVEC $6 \mathrm{~h}$}

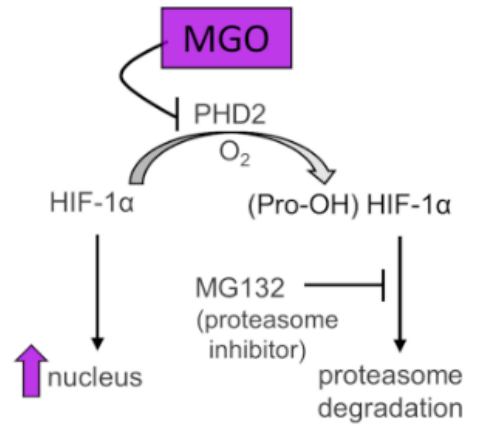

D
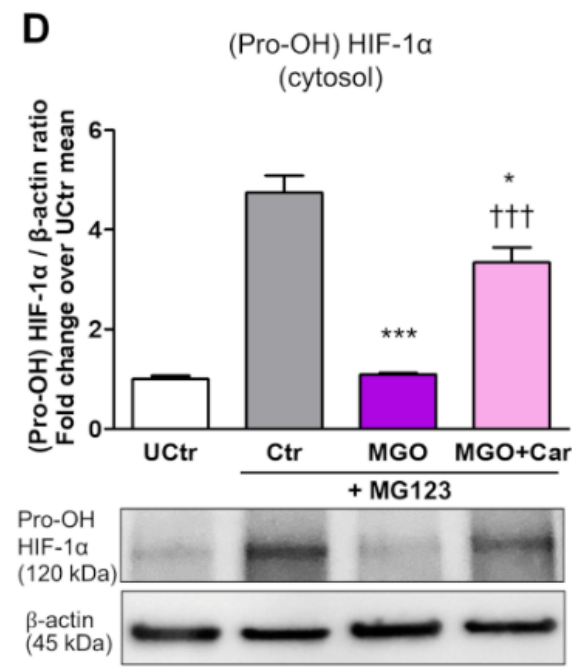

E

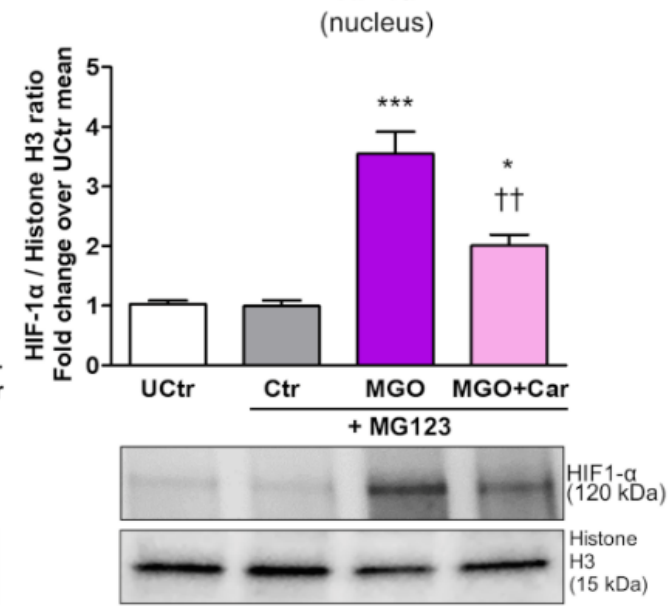

Figure 4. The glycolytic side-product MGO activates nuclear translocation of HIF- $1 \alpha$ by inducing post-translational glycation and inhibition of PHD2 activity. IP of MGO-protein adducts (MGO adds) (A) or PHD2 (B) on HUVEC treated (MGO) or not (Ctr) with $200 \mu \mathrm{M}$ MGO for $6 \mathrm{~h}$, using a specific antibody for MGO modified proteins (A) or a specific antiPHD2 antibody (B), respectively. Mouse IgG were used as control. Total cell lysates (Input) and immunoprecipitates were immunoblotted for PHD2 and MGO protein adducts (A,B). In the presence of oxygen, HIF- $1 \alpha$ is rapidly hydroxylated by PHD2 to generate (Pro-OH) HIF-1 $\alpha$, which is degraded through the ubiquitin-proteasome pathway; proteasome inhibition with MG132 led to Pro-OH HIF- $1 \alpha$ increase, and adding MGO prevented (Pro-OH) HIF- $1 \alpha$ increase and led to HIF- $1 \alpha$ nuclear translocation (C). Western blot analysis for (Pro-OH) HIF-1 $\alpha$ in total extracts (D), and non-hydroxylated HIF-1 $\alpha$ in nuclear extracts (E) from HUVEC, treated or untreated (UCtr) with the proteasome inhibitor MG132 $(10 \mu \mathrm{M})$ for $6 \mathrm{~h}$, with or without MGO, in the presence or absence of Car. Bars represent mean \pm SEM. Post hoc multiple comparison: *** $p<0.001$ or $* p<0.05$ vs. Ctr; $+\dagger+p<0.001$ or $+\dagger p<0.01$ vs. MGO. 


\subsection{Modulation of HIF-1 $\alpha$ Target Genes Related to Cellular Glucose Metabolism by MGO}

In HUVEC cultured in NG and treated with MGO, protein levels of the glycolytic enzymes HK2 (Figure 5A), PKM2 (Figure 5B), and LDHA (Figure 5C) were increased by $75 \%, 32 \%$, and $27 \%$, respectively.

A

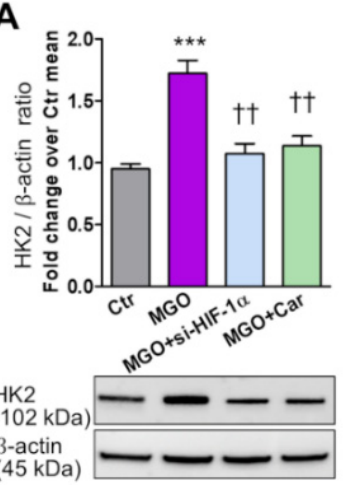

D

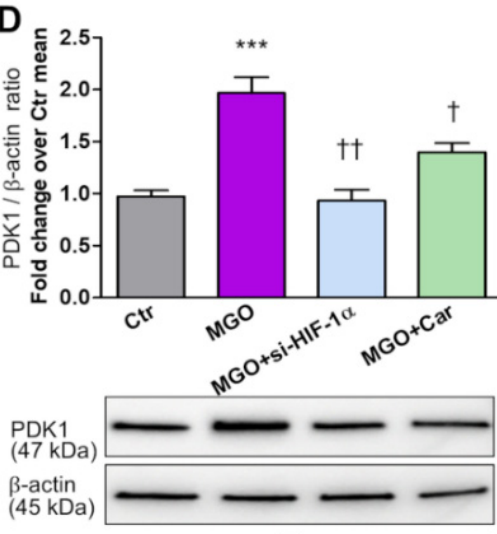

B

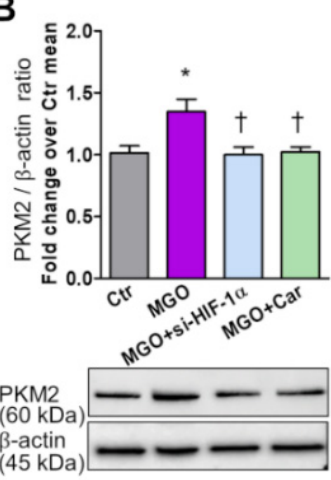

C

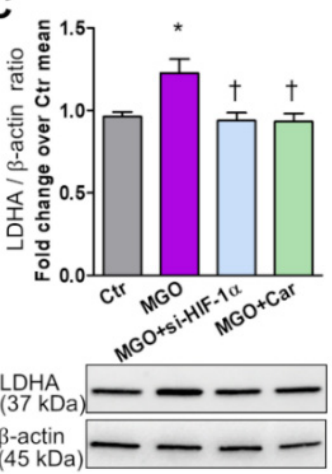

E

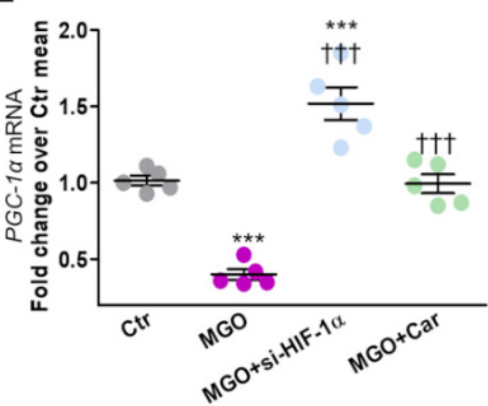

MGO
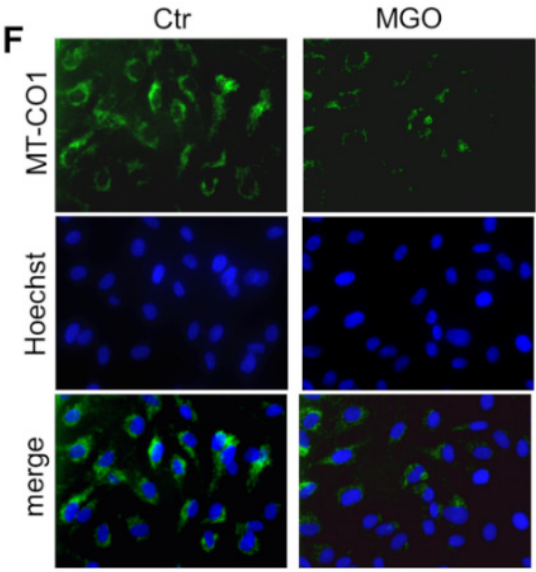

MGO+Car

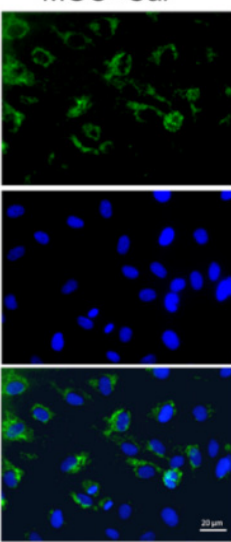

Figure 5. The glycolytic side-product MGO modulates HIF- $1 \alpha$ target genes related to cellular glucose metabolism. Western blot analysis of the glycolytic enzymes HK2 (A), PKM2 (B) and LDHA (C), and of the inhibitor of pyruvate dehydrogenase activity PDK1 (D) in total cell extracts from HUVEC treated (or untreated, $\mathrm{Ctr}=$ control) with the reactive dicarbonyl compound MGO $(200 \mu \mathrm{M})$ for 48 $\mathrm{h}$, silenced for HIF-1 $\alpha$ (si-HIF-1 $\alpha)$, or in the presence of the carbonyl trapping agent Car (20 mM), and relative band densitometry analysis from three separate experiments. mRNA levels of the mitochondrial biogenesis marker PGC-1 $\alpha$ (E) in HUVEC exposed to MGO for $48 \mathrm{~h}$, silenced for HIF- $1 \alpha$, or treated with Car; each dot represents the mean of two technical replicates of 5 wells per condition. Representative IF (F, scale bar $20 \mu \mathrm{m}$ ) for MT-CO1 in HUVEC treated or untreated (Ctr) with MGO for $48 \mathrm{~h}$, in the presence or absence of Car. Bars represent mean \pm SEM. Post hoc multiple comparison: ${ }^{* * *} p<0.001$ or $^{*} p<0.05$ vs. Ctr; $+\dagger+p<0.001,+\dagger p<0.01$ or $+p<0.05$ vs. MGO. 
Protein levels of PDK1, an inhibitor of mitochondrial respiration, increased 2-fold (Figure 5D), whereas mRNA levels of $P G C-1 \alpha$, a positive regulator of mitochondrial biogenesis, decreased by $60 \%$ (Figure 5E) in MGO-treated cells. si-HIF- $1 \alpha$ and Car treatment were both able to prevent the effects of MGO on glycolytic enzymes and mitochondrial function/biogenesis markers (Figure 5A-E). As compared with control cells, PGC-1 $\alpha$ was even upregulated in si-HIF- $1 \alpha$ cells (Figure 5E), a finding consistent with a feedback loop between $P G C-1 \alpha$ and HIF- $1 \alpha$-signaling in controlling the rate of oxygen consumption and mitochondrial respiration [30]. In vivo IF-based evaluation of MT-CO1, a key enzyme in aerobic metabolism, confirmed the inhibitory effect of MGO on mitochondrial respiration, and the protection provided by Car (Figure 5F).

\subsection{Contribution of HIF-1 $\alpha$-Related Cellular Energetic Changes to the Activation of the Alternative Pathological Pathways of Glucose Metabolism}

In HUVEC, both HG and MGO reduced oxygen consumption (by $77 \%$ and $65 \%$, respectively) at $60 \mathrm{~min}$ (Figure 6A,B) and increased lactate production (by $71 \%$ and $67 \%$, respectively) at $48 \mathrm{~h}$ (Figure $6 \mathrm{C}, \mathrm{D}$ ).
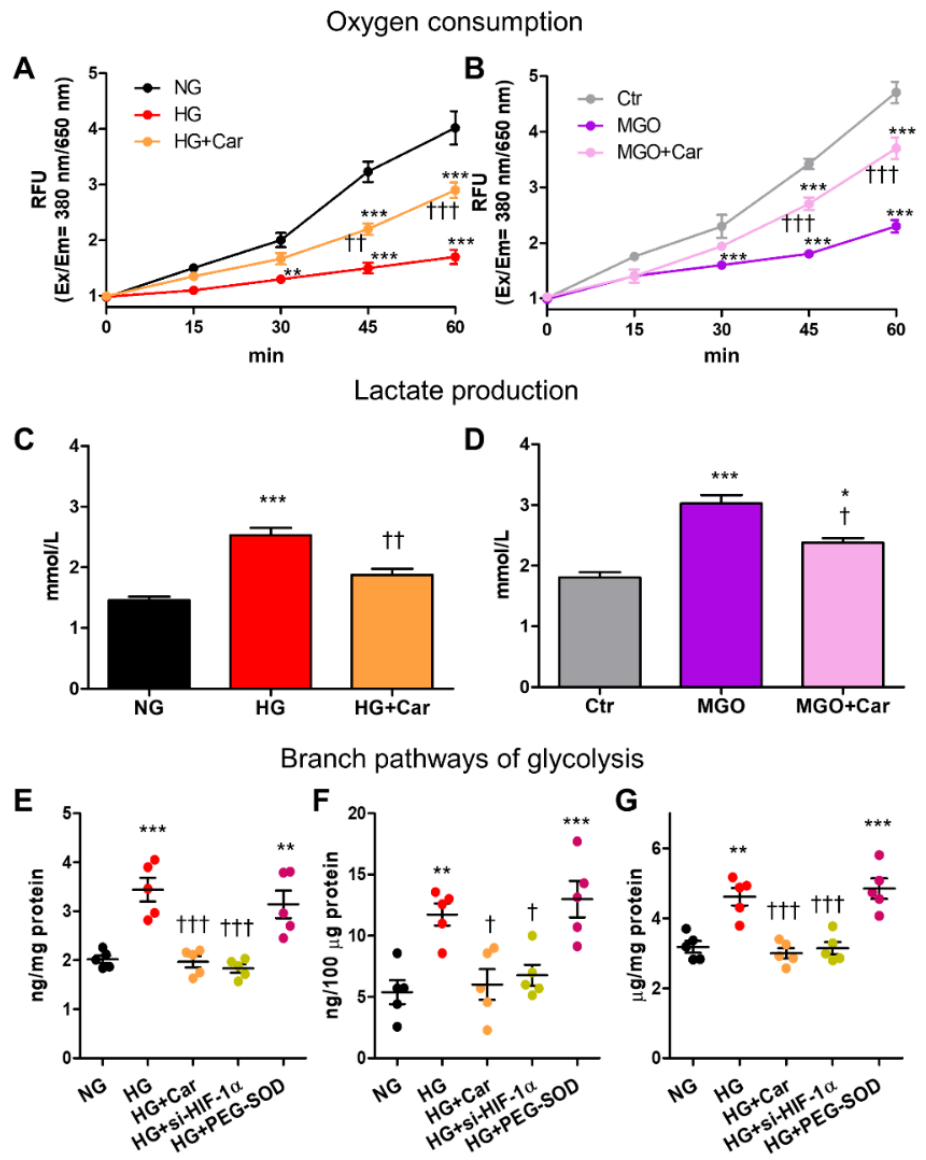

Figure 6. HG and the glycolytic side product MGO induce cellular energetic changes that resemble the Warburg effect and are associated with the activation of the alternative pathological pathways of glucose metabolism in HG conditions. Time course of oxygen consumption $(\mathbf{A}, \mathbf{B})$ and lactate production at $48 \mathrm{~h}(\mathbf{C}, \mathbf{D})$ by HUVEC exposed to HG $(20 \mathrm{mM})$ vs. NG $(5.5 \mathrm{mM})(\mathbf{A}, \mathbf{C})$, or treated with MGO $(200 \mu \mathrm{M})$ vs. untreated cells (Ctr) (B,D), with or without the carbonyl trapping agent Car (20 mM); $\mathrm{n}=3$ separate experiments in duplicate per condition. Hexosamine (E), polyol (F) and AGE (G) pathways activation in HUVEC exposed to HG vs. NG for $48 \mathrm{~h}$, with or without Car, as determined by measuring the levels of GFPT1 (E), D-sorbitol (F), and AGEs (G); each dot represents 
the mean of two technical replicates of 5 wells per condition. Bars represent mean \pm SEM. Post hoc multiple comparison: ${ }^{* *} p<0.001,{ }^{* *} p<0.01$ or ${ }^{*} p<0.05$ vs. NG or Ctr (as appropriate); ††+ $p<0.001,+\dagger p<0.01$ or $+p<0.05$ vs. HG or MGO (as appropriate).

Changes induced by HG and MGO in cellular glucose metabolism were significantly inhibited by Car (Figure 6A-D). In HG conditions, HIF- $1 \alpha$-related cellular energetic changes were paralleled by the activation of the glycolytic-side branches hexosamine pathway, as attested by the $70 \%$ increase in GFPT1 levels (Figure 6E), and polyol pathway, as demonstrated by the 2-fold increase in D-sorbitol (Figure 6F). As expected, AGE formation was also increased by HG treatment (+46\%, Figure 6G). Both si-HIF- $1 \alpha$ and Car treatment normalized the activity of the hexosamine and polyol pathways and prevented cellular accumulation of AGEs induced by HG (Figure 6E-G). Conversely, superoxide dismutation by PEG-SOD had no effect on the activity of the glycolytic side branches (Figure 6E-G).

\section{Discussion}

The accumulating evidence that mitochondrial superoxide generation is dispensable for the pathogenesis of vascular complications of diabetes [4-7]) compels us to search for new molecular triggers. This study provides a new mechanistic explanation, alternative to mitochondrial superoxide overproduction, for the initial changes in cellular metabolism of excess glucose and consequent biochemical abnormalities.

Here, we show that HIF- $1 \alpha$ stabilization was an initial event in the cellular biochemical abnormalities induced by diabetic glucose concentrations. HIF- $1 \alpha$-dependent metabolic reprogramming induced by HG resembled the Warburg effect, as glucose flux was shifted from mitochondrial oxidation to glycolysis and lactate production. In turn, the accumulating glycolytic intermediates were channeled into alternative pathways that branch off from the glycolytic route and are known contributors to diabetic complications (i.e., polyol, hexosamine, and AGE pathways) [3,31]. The bioenergetic changes induced by HG were reversed by si-HIF-1 $\alpha$. Moreover, the carbonyl-trapping agent Car and the GLO1 inducer Res were able to inhibit HG-induced HIF- $1 \alpha$ activation, suggesting a role for MGO, a toxic glucose metabolite produced from the spontaneous degradation of triose phosphates, the levels of which are increased when cells are exposed to glucose concentrations in the diabetic range [23,24]. Consistently, MGO was able to reproduce all the molecular, metabolic, and biochemical changes induced by HG, from HIF-1 $\alpha$ stabilization and activity to endothelial cell and macrophage activation. Mechanistically, MGO induced HIF- $1 \alpha$ nuclear translocation by interacting with PHD2, the main PHD isoenzyme responsible for HIF- $1 \alpha$ degradation in normoxia [32], resulting in diminished enzyme activity.

These findings are consistent with the demonstration that, in mesangial and endothelial cells, HG activates HIF- $1 \alpha$ and its target genes known to be involved in the development of micro- and macrovascular complications of diabetes $[19,20]$. It is also in line with a recent report showing that lactate production was increased in hyperglycemic myotubes in the absence of ROS generation [33]. However, it is at odds with the finding that, under hypoxic conditions, HIF- $1 \alpha$ was inhibited by HG in renal proximal tubular cells $[34,35]$, suggesting an impaired HIF- $1 \alpha$-dependent response to hypoxia in diabetes [36]. Actually, these apparently contrasting data may reflect differences in environmental conditions (normoxia versus hypoxia) and possibly cell type [36], suggesting that HIF-1 $\alpha$ may serve as the initial trigger of glucotoxicity under normoxia by inducing a Warburg effect, but also mediate adaptation to tissue hypoxia, which is known to play a key role in diabetes-associated end-organ damage [37-39]. Therefore, while detrimental in an early phase, HIF- $1 \alpha$ activity might exert a favorable effect in advanced disease by contrasting hypoxia. Results of in vivo studies in experimental animal models might also reflect this dual role of HIF- $1 \alpha$ in diabetes-related vascular damage. On the one hand, HIF- $1 \alpha$ activation was shown to promote atherosclerosis initiation and progression $[40,41]$ as well as hypoxia-induced renal fibrogenesis [42-44] by stimulating epithelial-to-mesenchymal transition [45] and a2(I) collagen expression through interactions with Smad3 [46]. On the other hand, the HIF-1A 
Pro582Ser polymorphism, which confers less sensitivity to the inhibitory effect of glucose during a hypoxic challenge, was shown to be protective toward development of advanced diabetic nephropathy [47] and retinopathy [48]. In addition, inhibitors of PHDs provided protection against atherosclerosis in LDL receptor-deficient mice [49], and improved post-ischemia myocardial dysfunction [38] and renal metabolic abnormalities [50,51] in experimental models of diabetes. However, it is unclear whether renoprotection was mechanistically linked to the activation of HIF- $1 \alpha$ or, rather, of the HIF- $2 \alpha$ isoform, which is a key regulator of renal erythropoiesis [21,52] and a potential new target for the treatment of anemia in chronic kidney disease [53]. Furthermore, PHD2 overexpression attenuated the profibrotic effect of albumin in cultured renal tubular cells [54], whereas PHD2 ablation promoted renal vascular remodeling and fibrosis in mice [55], suggesting a detrimental role of unrestricted HIF- $1 \alpha$ activity.

Known target genes of HIF- $1 \alpha$ drove upregulated glycolysis and repressed mitochondrial respiration. In fact, HIF- $1 \alpha$ induction was associated with an overexpression of the negative regulator of mitochondrial respiration PDK1 and the glycolytic enzymes HK, PKM2, LDH, whereas the mRNA levels of PGC-1 $\alpha$, an inducer of mitochondrial biogenesis and function, were reduced. At first view, our findings seem to be at odds with recent proteomic studies in individuals with very long diabetes duration ( $\geq 50$ years), which indicated that glycolytic enzymes, particularly PKM2, were elevated in glomeruli and plasma of patients without diabetic nephropathy compared with patients with this complication, thus suggesting a protective role for PKM2 by increasing glucose flux through glycolysis [56,57]. It is known that PKM2 is modulated by HIF-1 $\alpha$ [28] and cooperates with it in the regulation of aerobic glycolysis [58-60]. However, at variance with the constitutively active (i.e., tetrameric) PKM1 isoform, PKM2 is mainly present in a dimeric form, which is much less active in catalyzing the last step within glycolysis, thus favoring accumulation of upstream glycolytic metabolites, as occurs in cancer cells [61]. Conversely, in its dimeric form, PKM2 displays a unique gene regulatory function, complementary to that of HIF- $1 \alpha$, in the establishment of the Warburg effect [62]. Therefore, it may be speculated that, in diabetic patients without nephropathy, undetermined allosteric effectors stabilize PKM2 tetrameric assembly, thus favoring the glycolytic over the transcriptional regulator activity and the re-activation of mitochondrial oxidative metabolism. This interpretation is consistent with previous findings in preclinical models of diabetic nephropathy by several investigators [63,64], including Qi et al. [56], showing that pharmacological activation of PKM2 was associated with recovered mitochondrial function and biogenesis, suppressed HIF- $1 \alpha$ and lactate accumulation, blunted elevation in toxic glucose metabolites, and reduced renal inflammation and fibrosis.

Diabetes is also considered a "chemical" disorder, as its long-term sequelae are the result of broad-based alterations in the chemical structure of biological molecules [65]. The hypothesis of HIF- $1 \alpha$ induction as an early trigger of glucotoxicity combines metabolic and chemical mechanisms: higher intracellular glucose flux inevitably leads to increased MGO production, non-enzymatic post-translational glycation and PHD2 inhibition, with consequent HIF- $1 \alpha$-dependent reprogramming of cellular glucose metabolism (i.e., Warburg effect), persistent elevation of glycolytic intermediates, and feeding of the biochemical (polyol, hexosamine, and AGE) pathways leading to cell injury. This is consistent with several studies showing that Car, or its derivatives, protected diabetic mice from vascular complications [66-68] and that protection was associated with hindered HIF- $1 \alpha$ upregulation in the vasculature of type 1 [67] and liver of type 2 [69] diabetic mice. In addition, it is in keeping with the findings that Glo1 knockdown in nondiabetic mice mimics [70], whereas Glo1 overexpression in diabetic animals improves [71] microvascular pathology. The implication of this mechanistic hypothesis is that HIF- $1 \alpha$ mediated metabolic reprogramming is sufficient, whereas mitochondrial superoxide production is dispensable, for inducing vascular cell activation, inflammation and AGE accumulation, three well recognized contributors to vascular dysfunction and pathology in diabetes $[2,3,31]$. 
Although our results argue against mitochondrial superoxide production as the initial trigger, they do not exclude the detrimental role of oxidative stress in vascular complications of diabetes, as most of the pathways that branch off from glycolysis produce reactive oxygen species [2,72,73], including mitochondrial superoxide generated in response to AGE binding to their receptor $[74,75]$. The concept that oxidative stress is a downstream event, not the initiator of the cellular events triggered by glucose, may explain the failure of clinical trials to prove a clear benefit of antioxidants in diabetic patients [76], though other mechanisms may be responsible for these discouraging results [77]. Finally, considering that not all reactive carbonyls require increased oxidative stress for their formation in vivo [65], carbonyl stress, intended as an increased production of glycolytic, non-oxidatively derived carbonyls such as MGO, is a more likely candidate than oxidative stress as initial mediator of glucotoxicity. This implies that interventions using carbonyl sequestering agents and/or inducers of the glyoxalase pathway may be more effective than antioxidants in preventing vascular complications [66-71].

The main limitation of this study is the lack of in vivo data. However, direct targeting of HIF- $1 \alpha$ or PHD2 in diabetic animal models cannot provide further comprehension of their role in the instigation of the initial cellular biochemical abnormalities induced by hyperglycemia, which is the aim of this study. Another limitation may be the lack of specificity of Car and Res in protecting from glucose-induced changes of HIF- $1 \alpha$ activity, as these compounds have other pleiotropic effects beyond their MGO-sequestering and GLO-1 inducer activities. In fact, both Car and Res have been shown to exert indirect antioxidant effects to upregulate endogenous antioxidants and other cell stress response genes [78-81]. However, the efficacy of Car to prevent HIF- $\alpha$ changes induced by MGO, including the reduced prolyl hydroxylation by PHD2, can only be attributed to its carbonyl trapping activity, thus supporting the concept that the protective effects exerted by both compounds in HG conditions were mediated by their ability to prevent glycolysis-induced MGO accumulation.

\section{Conclusions}

In conclusion, this study identifies HIF- $1 \alpha$ and related cellular energetic changes (i.e., Warburg effect) as early and essential components of a metabolic and chemical process that mediates the injurious effect of hyperglycemia, leading to cell activation and inflammation.

Supplementary Materials: The following are available online at https:/ / www.mdpi.com/article / 10.3390/biomedicines9091139/s1, Figure S1. Mannitol $20 \mathrm{mM}$ does not induce HIF-1 $\alpha$ activity and proinflammatory cell activation in endothelial cells and LPS-stimulated macrophages.

Author Contributions: C.I. and M.V. contributed to conceptualization, methodology, investigation, validation and writing-review \& editing; G.P. contributed to supervision, data curation, formal analysis and writing-original draft; S.M. contributed to conceptualization, funding acquisition, project administration, formal analysis, visualization, writing-original draft. S.M. and G.P. are the guarantors of this work and, as such, had full access to all the data in the study and take responsibility for the integrity of the data and the accuracy of the data analysis. All authors have read and agreed to the published version of the manuscript.

Funding: This work was supported by a research grant from the European Foundation for the Study of Diabetes (EFSD)/Sanofi European Diabetes Research Programme in Macrovascular Complications 2019, and Sapienza University of Rome-Progetti di Ateneo 2017 and 2020 to SM. The funding sources had no involvement in study design; in the collection, analysis and interpretation of data; in the writing of the report; and in the decision to submit the article for publication.

Institutional Review Board Statement: Not applicable.

Informed Consent Statement: Not applicable.

Data Availability Statement: The datasets used and/or analysed during the current study are available from the corresponding author on reasonable request.

Conflicts of Interest: The authors declare that they have no competing interest. 


\begin{abstract}
Abbreviations
AGEs = advanced glycation end-products; Car = L-Carnosine; GLO1 = glyoxalase-1; HCAEC = human coronary artery endothelial cells; HG = high glucose; HIF- $1 \alpha=$ hypoxia-inducible factor- $1 \alpha$; HK2 = hexokinase 2; HUVEC = human umbilical vein endothelial cells; $I L-1 \beta=$ interleukin $1 \beta$; LDHA = lactate dehydrogenase A; LPS = lipopolysaccharide; $M C P-1 / C C L 2$ = monocyte chemoattractant protein-1/C-C motif chemokine ligand 2; $\mathrm{MGO}=$ methylglyoxal; PDK1 = pyruvate dehydrogenase kinase $1 ; P G C-1 \alpha=$ peroxisome proliferator-activated receptor gamma coactivator $1-\alpha$; PHD2/EGLN1 = prolyl hydroxylase domain-containing protein 2/egl-9 family hypoxia inducible factor 1; PKM2 = pyruvate kinase M2; Pro-OH = proline-hydroxylated; Res = trans-resveratrol; RT$\mathrm{PCR}=$ real time PCR; TNF- $\alpha=$ tumor necrosis factor- $\alpha ; V C A M-1=$ vascular cell adhesion molecule 1.
\end{abstract}

\title{
References
}

1. Beckman, J.A.; Creager, M.A. Vascular Complications of Diabetes. Circ. Res. 2016, 118, 1771-1785. [CrossRef]

2. Rask-Madsen, C.; King, G.L. Vascular Complications of Diabetes: Mechanisms of Injury and Protective Factors. Cell Metab. 2013, 17, 20-33. [CrossRef]

3. Brownlee, M. Biochemistry and Molecular Cell Biology of Diabetic Complications. Nature 2001, 414, 813-820. [CrossRef]

4. Sourris, K.C.; Harcourt, B.E.; Tang, P.H.; Morley, A.L.; Huynh, K.; Penfold, S.A.; Coughlan, M.T.; Cooper, M.E.; Nguyen, T.V.; Ritchie, R.H.; et al. Ubiquinone (Coenzyme Q10) Prevents Renal Mitochondrial Dysfunction in an Experimental Model of Type 2 Diabetes. Free Radic. Biol. Med. 2012, 52, 716-723. [CrossRef]

5. Dugan, L.L.; You, Y.H.; Ali, S.S.; Diamond-Stanic, M.; Miyamoto, S.; DeCleves, A.E.; Andreyev, A.; Quach, T.; Ly, S.; Shekhtman, G.; et al. AMPK Dysregulation Promotes Diabetes-Related Reduction of Superoxide and Mitochondrial Function. J. Clin. Investig. 2013, 123, 4888-4899. [CrossRef] [PubMed]

6. Miyamoto, S.; Zhang, G.; Hall, D.; Oates, P.J.; Maity, S.; Madesh, M.; Han, X.; Sharma, K. Restoring Mitochondrial Superoxide Levels with Elamipretide (MTP-131) Protects Db/Db Mice against Progression of Diabetic Kidney Disease. J. Biol. Chem. 2020, 295, 7249-7260. [CrossRef] [PubMed]

7. Coughlan, M.T.; Sharma, K. Challenging the Dogma of Mitochondrial Reactive Oxygen Species Overproduction in Diabetic Kidney Disease. Kidney Int. 2016, 90, 272-279. [CrossRef] [PubMed]

8. Forbes, J.M.; Fotheringham, A.K. Vascular Complications in Diabetes: Old Messages, New Thoughts. Diabetologia 2017, 60, 2129-2138. [CrossRef] [PubMed]

9. Semenza, G.L. Oxygen Sensing, Homeostasis, and Disease. N. Eng. J. Med. 2011, 365, 537-547. [CrossRef]

10. Semenza, G.L. Regulation of Oxygen Homeostasis by Hypoxia-Inducible Factor 1. Physiology 2009, 24, 97-106. [CrossRef]

11. Seagroves, T.N.; Ryan, H.E.; Lu, H.; Wouters, B.G.; Knapp, M.; Thibault, P.; Laderoute, K.; Johnson, R.S. Transcription Factor HIF-1 Is a Necessary Mediator of the Pasteur Effect in Mammalian Cells. Mol. Cell Biol. 2001, 21, 3436-3444. [CrossRef]

12. Lum, J.J.; Bui, T.; Gruber, M.; Gordan, J.D.; DeBerardinis, R.J.; Covello, K.L.; Simon, M.C.; Thompson, C.B. The Transcription Factor HIF-1 Plays a Critical Role in the Growth Factor-Dependent Regulation of Both Aerobic and Anaerobic Glycolysis. Genes Dev. 2007, 21, 1037-1049. [CrossRef]

13. Semenza, G.L. Hypoxia-Inducible Factors in Physiology and Medicine. Cell 2012, 148, 399-408. [CrossRef] [PubMed]

14. Kaelin, W.G.; Ratcliffe, P.J. Oxygen Sensing by Metazoans: The Central Role of the HIF Hydroxylase Pathway. Mol. Cell 2008, 30, 393-402. [CrossRef]

15. Papandreou, I.; Cairns, R.A.; Fontana, L.; Lim, A.L.; Denko, N.C. HIF-1 Mediates Adaptation to Hypoxia by Actively Downregulating Mitochondrial Oxygen Consumption. Cell Metab. 2006, 3, 187-197. [CrossRef] [PubMed]

16. McGettrick, A.F.; O'Neill, L.A.J. How Metabolism Generates Signals during Innate Immunity and Inflammation. J. Biol. Chem. 2013, 288, 22893-22898. [CrossRef] [PubMed]

17. Cramer, T.; Yamanishi, Y.; Clausen, B.E.; Förster, I.; Pawlinski, R.; Mackman, N.; Haase, V.H.; Jaenisch, R.; Corr, M.; Nizet, V.; et al. HIF- $1 \alpha$ Is Essential for Myeloid Cell-Mediated Inflammation. Cell 2003, 112, 645-657. [CrossRef]

18. Wen, H.; Ting, J.P.Y.; O'Neill, L.A.J. A Role for the NLRP3 Inflammasome in Metabolic Diseases—Did Warburg Miss Inflammation? Nat. Immunol. 2012, 13, 352-357. [CrossRef] [PubMed]

19. Isoe, T.; Makino, Y.; Mizumoto, K.; Sakagami, H.; Fujita, Y.; Honjo, J.; Takiyama, Y.; Itoh, H.; Haneda, M. High Glucose Activates HIF-1-Mediated Signal Transduction in Glomerular Mesangial Cells through a Carbohydrate Response Element Binding Protein. Kidney Int. 2010, 78, 48-59. [CrossRef] [PubMed]

20. Li, R.; Uttarwar, L.; Gao, B.; Charbonneau, M.; Shi, Y.; Chan, J.S.D.; Dubois, C.M.; Krepinsky, J.C. High Glucose Up-Regulates ADAM17 through HIF-1 $\beta$ in Mesangial Cells. J. Biol. Chem. 2015, 290, 21603-21614. [CrossRef] [PubMed]

21. Packer, M. Mechanisms Leading to Differential Hypoxia-Inducible Factor Signaling in the Diabetic Kidney: Modulation by SGLT2 Inhibitors and Hypoxia Mimetics. Am. J. Kidney Dis. 2021, 77, 280-286. [CrossRef] [PubMed]

22. Anderson, E.J.; Vistoli, G.; Katunga, L.A.; Funai, K.; Regazzoni, L.; Blake Monroe, T.; Gilardoni, E.; Cannizzaro, L.; Colzani, M.; de Maddis, D.; et al. A Carnosine Analog Mitigates Metabolic Disorders of Obesity by Reducing Carbonyl Stress. J. Clin. Investig. 2018, 128, 5280-5293. [CrossRef] [PubMed] 
23. Nokin, M.J.; Durieux, F.; Peixoto, P.; Chiavarina, B.; Peulen, O.; Blomme, A.; Turtoi, A.; Costanza, B.; Smargiasso, N.; Baiwir, D.; et al. Methylglyoxal, a Glycolysis Side-Product, Induces Hsp90 Glycation and YAP- Mediated Tumor Growth and Metastasis. eLife 2016, 5, e19375. [CrossRef]

24. Phillips, S.A.; Thornalley, P.J. The Formation of Methylglyoxal from Triose Phosphates: Investigation Using a Specific Assay for Methylglyoxal. Eur. J. Biochem. 1993, 212, 101-105. [CrossRef] [PubMed]

25. Sousa Silva, M.; Gomes, R.A.; Ferreira, A.E.N.; Ponces Freire, A.; Cordeiro, C. The Glyoxalase Pathway: The First Hundred Years... and Beyond. Biochem. J. 2013, 453, 1-15. [CrossRef] [PubMed]

26. Xue, M.; Weickert, M.O.; Qureshi, S.; Kandala, N.B.; Anwar, A.; Waldron, M.; Shafie, A.; Messenger, D.; Fowler, M.; Jenkins, G.; et al. Improved Glycemic Control and Vascular Function in Overweight and Obese Subjects by Glyoxalase 1 Inducer Formulation. Diabetes 2016, 65, 2282-2294. [CrossRef]

27. Anastasiou, D.; Yu, Y.; Israelsen, W.J.; Jiang, J.K.; Boxer, M.B.; Hong, B.S.; Tempel, W.; Dimov, S.; Shen, M.; Jha, A.; et al. Pyruvate Kinase M2 Activators Promote Tetramer Formation and Suppress Tumorigenesis. Nat. Chem. Biol. 2012, 8, 839-847. [CrossRef]

28. Semenza, G.L.; Roth, P.H.; Fang, H.M.; Wang, G.L. Transcriptional Regulation of Genes Encoding Glycolytic Enzymes by Hypoxia-Inducible Factor 1. J. Biol. Chem. 1994, 269, 23757-23763. [CrossRef]

29. Zhang, H.; Gao, P.; Fukuda, R.; Kumar, G.; Krishnamachary, B.; Zeller, K.I.; Dang, C.V.; Semenza, G.L. HIF-1 Inhibits Mitochondrial Biogenesis and Cellular Respiration in VHL-Deficient Renal Cell Carcinoma by Repression of C-MYC Activity. Cancer Cell 2007, 11, 407-420. [CrossRef]

30. O’Hagan, K.A.; Cocchiglia, S.; Zhdanov, A.; Tambawala, M.M.; Cummins, E.P.; Monfared, M.; Agbor, T.A.; Garvey, J.F.; Papkovsky, D.B.; Taylor, C.T.; et al. PGC-1 $\alpha$ Is Coupled to HIF-1 $\alpha$-Dependent Gene Expression by Increasing Mitochondrial Oxygen Consumption in Skeletal Muscle Cells. Proc. Natl. Acad. Sci. USA 2009, 106, 2188-2193. [CrossRef]

31. Brownlee, M. The Pathobiology of Diabetic Complications: A Unifying Mechanism. Diabetes 2005, 54, 1615-1625. [CrossRef]

32. Berra, E.; Benizri, E.; Ginouvès, A.; Volmat, V.; Roux, D.; Pouysségur, J. HIF Prolyl-Hydroxylase 2 Is the Key Oxygen Sensor Setting Low Steady-State Levels of HIF-1 $\alpha$ in Normoxia. EMBO J. 2003, 22, 4082-4090. [CrossRef] [PubMed]

33. Lund, J.; Ouwens, D.M.; Wettergreen, M.; Bakke, S.S.; Thoresen, G.H.; Aas, V. Increased Glycolysis and Higher Lactate Production in Hyperglycemic Myotubes. Cells 2019, 8, 1101. [CrossRef]

34. Catrina, S.B.; Okamoto, K.; Pereira, T.; Brismar, K.; Poellinger, L. Hyperglycemia Regulates Hypoxia-Inducible Factor-1 $\alpha$ Protein Stability and Function. Diabetes 2004, 53, 3226-3232. [CrossRef] [PubMed]

35. García-Pastor, C.; Benito-Martínez, S.; Moreno-Manzano, V.; Fernández-Martínez, A.B.; Lucio-Cazaña, F.J. Mechanism and Consequences of the Impaired Hif- $1 \alpha$ Response to Hypoxia in Human Proximal Tubular HK-2 Cells Exposed to High Glucose. Sci. Rep. 2019, 9, 15868. [CrossRef] [PubMed]

36. Catrina, S.B.; Zheng, X. Hypoxia and Hypoxia-Inducible Factors in Diabetes and Its Complications. Diabetologia 2021, 64, 709-716. [CrossRef] [PubMed]

37. Thomas, M.C.; Cooper, M.E.; Rossing, K.; Parving, H.H. Anaemia in Diabetes: Is There a Rationale to TREAT? Diabetologia 2006, 49, 1151-1157. [CrossRef]

38. Marfella, R.; Esposito, K.; Nappo, F.; Siniscalchi, M.; Sasso, F.C.; Portoghese, M.; di Marino, M.P.; Baldi, A.; Cuzzocrea, S.; di Filippo, C.; et al. Expression of Angiogenic Factors during Acute Coronary Syndromes in Human Type 2 Diabetes. Diabetes 2004, 53, 2383-2391. [CrossRef]

39. Hesp, A.C.; Schaub, J.A.; Prasad, P.; Vallon, V.; Laverman, G.D.; Bjornstad, P.; van Raalte, D.H. The Role of Renal Hypoxia in the Pathogenesis of Diabetic Kidney Disease: A Promising Target for Newer Renoprotective Agents Including SGLT2 Inhibitors? Kidney Int. 2020, 98, 579-589. [CrossRef]

40. Feng, S.; Bowden, N.; Fragiadaki, M.; Souilhol, C.; Hsiao, S.; Mahmoud, M.; Allen, S.; Pirri, D.; Ayllon, B.T.; Akhtar, S.; et al. Mechanical Activation of Hypoxia-Inducible Factor 1a Drives Endothelial Dysfunction at Atheroprone Sites. Arterioscler. Thromb. Vasc. Biol. 2017, 37, 2087-2101. [CrossRef]

41. Gao, L.; Chen, Q.; Zhou, X.; Fan, L. The Role of Hypoxia-Inducible Factor 1 in Atherosclerosis. J. Clin. Pathol. 2012, 65, 872-876. [CrossRef]

42. Matoba, K.; Kawanami, D.; Okada, R.; Tsukamoto, M.; Kinoshita, J.; Ito, T.; Ishizawa, S.; Kanazawa, Y.; Yokota, T.; Murai, N.; et al. Rho-Kinase Inhibition Prevents the Progression of Diabetic Nephropathy by Downregulating Hypoxia-Inducible Factor $1 \alpha$. Kidney Int. 2013, 84, 545-554. [CrossRef] [PubMed]

43. Nayak, B.K.; Shanmugasundaram, K.; Friedrichs, W.E.; Cavaglierii, R.C.; Patel, M.; Barnes, J.; Block, K. HIF-1 Mediates Renal Fibrosis in OVE26 Type 1 Diabetic Mice. Diabetes 2016, 65, 1387-1397. [CrossRef] [PubMed]

44. Makino, H.; Miyamoto, Y.; Sawai, K.; Mori, K.; Mukoyama, M.; Nakao, K.; Yoshimasa, Y.; Suga, S.I. Altered Gene Expression Related to Glomerulogenesis and Podocyte Structure in Early Diabetic Nephropathy of Db/Db Mice and Its Restoration by Pioglitazone. Diabetes 2006, 55, 2747-2756. [CrossRef] [PubMed]

45. Higgins, D.F.; Kimura, K.; Bernhardt, W.M.; Shrimanker, N.; Akai, Y.; Hohenstein, B.; Saito, Y.; Johnson, R.S.; Kretzler, M.; Cohen, C.D.; et al. Hypoxia Promotes Fibrogenesis In Vivo via HIF-1 Stimulation of Epithelial-to-Mesenchymal Transition. J. Clin. Investig. 2007, 117, 3810-3820. [CrossRef]

46. Baumann, B.; Hayashida, T.; Liang, X.; Schnaper, H.W. Hypoxia-Inducible Factor-1 $\alpha$ Promotes Glomerulosclerosis and Regulates COL1A2 Expression through Interactions with Smad3. Kidney Int. 2016, 90, 797-808. [CrossRef] 
47. Gu, H.F.; Zheng, X.; Seman, N.A.; Gu, T.; Botusan, I.R.; Sunkari, V.G.; Lokman, E.F.; Brismar, K.; Catrina, S.B. Impact of the Hypoxia-Inducible Factor-1 $\alpha$ (HIF1A) Pro582Ser Polymorphism on Diabetes Nephropathy. Diabetes Care 2013, 36, $415-421$. [CrossRef]

48. Ekberg, N.R.; Eliasson, S.; Li, Y.W.; Zheng, X.; Chatzidionysiou, K.; Falhammar, H.; Gu, H.F.; Catrina, S.B. Protective Effect of the HIF-1A Pro582Ser Polymorphism on Severe Diabetic Retinopathy. J. Diabetes Res. 2019, 2019, 2936962. [CrossRef]

49. Rahtu-Korpela, L.; Määttä, J.; Dimova, E.Y.; Hörkkö, S.; Gylling, H.; Walkinshaw, G.; Hakkola, J.; Kivirikko, K.I.; Myllyharju, J.; Serpi, R.; et al. Hypoxia-Inducible Factor Prolyl 4-Hydroxylase-2 Inhibition Protects Against Development of Atherosclerosis. Arterioscler. Thromb. Vasc. Biol. 2016, 36, 608-617. [CrossRef]

50. Sugahara, M.; Tanaka, S.; Tanaka, T.; Saito, H.; Ishimoto, Y.; Wakashima, T.; Ueda, M.; Fukui, K.; Shimizu, A.; Inagi, R.; et al. Prolyl Hydroxylase Domain Inhibitor Protects against Metabolic Disorders and Associated Kidney Disease in Obese Type 2 Diabetic Mice. J. Am. Soc. Nephrol. 2020, 31, 560-577. [CrossRef]

51. Hasegawa, S.; Tanaka, T.; Saito, T.; Fukui, K.; Wakashima, T.; Susaki, E.A.; Ueda, H.R.; Nangaku, M. The Oral Hypoxia-Inducible Factor Prolyl Hydroxylase Inhibitor Enarodustat Counteracts Alterations in Renal Energy Metabolism in the Early Stages of Diabetic Kidney Disease. Kidney Int. 2020, 97, 934-950. [CrossRef]

52. Eckardt, K.U.; Kurtz, A. Regulation of Erythropoietin Production. Eur. J. Clin. Investig. 2005, 35, 13-19. [CrossRef]

53. Gupta, N.; Wish, J.B. Hypoxia-Inducible Factor Prolyl Hydroxylase Inhibitors: A Potential New Treatment for Anemia in Patients with CKD. Am. J. Kid Dis. 2017, 69, 815-826. [CrossRef] [PubMed]

54. Hu, J.; Wang, W.; Zhang, F.; Li, P.L.; Boini, K.M.; Yi, F.; Li, N. Hypoxia Inducible Factor-1 $\alpha$ Mediates the Profibrotic Effect of Albumin in Renal Tubular Cells. Sci. Rep. 2017, 7, 15878. [CrossRef] [PubMed]

55. Wang, S.; Zeng, H.; Chen, S.T.; Zhou, L.; Xie, X.J.; He, X.; Tao, Y.K.; Tuo, Q.H.; Deng, C.; Liao, D.F.; et al. Ablation of Endothelial Prolyl Hydroxylase Domain Protein-2 Promotes Renal Vascular Remodelling and Fibrosis in Mice. J. Cell Mol. Med. 2017, 21, 1967-1978. [CrossRef]

56. Qi, W.; Keenan, H.A.; Li, Q.; Ishikado, A.; Kannt, A.; Sadowski, T.; Yorek, M.A.; Wu, I.H.; Lockhart, S.; Coppey, L.J.; et al. Pyruvate Kinase M2 Activation May Protect against the Progression of Diabetic Glomerular Pathology and Mitochondrial Dysfunction. Nat. Med. 2017, 23, 753-762. [CrossRef]

57. Gordin, D.; Shah, H.; Shinjo, T.; St-Louis, R.; Qi, W.; Park, K.; Paniagua, S.M.; Pober, D.M.; Wu, I.H.; Bahnam, V.; et al. Characterization of Glycolytic Enzymes and Pyruvate Kinase M2 in Type 1 and 2 Diabetic Nephropathy. Diabetes Care 2019, 42, 1263-1273. [CrossRef]

58. Luo, W.; Hu, H.; Chang, R.; Zhong, J.; Knabel, M.; O’Meally, R.; Cole, R.N.; Pandey, A.; Semenza, G.L. Pyruvate Kinase M2 Is a PHD3-Stimulated Coactivator for Hypoxia-Inducible Factor 1. Cell 2011, 145, 732-744. [CrossRef] [PubMed]

59. Wong, N.; Ojo, D.; Yan, J.; Tang, D. PKM2 Contributes to Cancer Metabolism. Cancer Lett. 2015, 356, 184-191. [CrossRef]

60. Palsson-Mcdermott, E.M.; Curtis, A.M.; Goel, G.; Lauterbach, M.A.R.; Sheedy, F.J.; Gleeson, L.E.; van den Bosch, M.W.M.; Quinn, S.R.; Domingo-Fernandez, R.; Johnston, D.G.W.; et al. Pyruvate Kinase M2 Regulates Hif- $1 \alpha$ Activity and IL-1 $\beta$ Induction and Is a Critical Determinant of the Warburg Effect in Lps-Activated Macrophages. Cell Metab. 2015, 21, 65-80. [CrossRef] [PubMed]

61. Luo, W.; Semenza, G.L. Pyruvate Kinase M2 Regulates Glucose Metabolism by Functioning as a Coactivator for Hypoxia-Inducible Factor 1 in Cancer Cells. Oncotarget 2011, 2, 551-556. [CrossRef]

62. Wang, Y.; Liu, J.; Jin, X.; Zhang, D.; Li, D.; Hao, F.; Feng, Y.; Gu, S.; Meng, F.; Tian, M.; et al. O-GlcNAcylation Destabilizes the Active Tetrameric PKM2 to Promote the Warburg Effect. Proc. Natl. Acad. Sci. USA 2017, 114, 13732-13737. [CrossRef] [PubMed]

63. Li, L.; Tang, L.; Yang, X.; Chen, R.; Zhang, Z.; Leng, Y.; Chen, A.F. Gene Regulatory Effect of Pyruvate Kinase M2 Is Involved in Renal Inflammation in Type 2 Diabetic Nephropathy. Exp. Clin. Endocrinol. Diabetes 2020, 128, 599-606. [CrossRef] [PubMed]

64. Liu, H.; Takagaki, Y.; Kumagai, A.; Kanasaki, K.; Koya, D. The PKM2 Activator TEPP-46 Suppresses Kidney Fibrosis via Inhibition of the EMT Program and Aberrant Glycolysis Associated with Suppression of HIF-1 $\alpha$ Accumulation. J. Diabetes Investig. 2021, 12, 697-709. [CrossRef]

65. Baynes, J.W.; Thorpe, S.R. Role of Oxidative Stress in Diabetic Complications: A New Perspective on an Old Paradigm. Diabetes 1999, 48, 1-9. [CrossRef]

66. Menini, S.; Iacobini, C.; Ricci, C.; Scipioni, A.; Fantauzzi, C.B.; Giaccari, A.; Salomone, E.; Canevotti, R.; Lapolla, A.; Orioli, M.; et al. D-Carnosine Octylester Attenuates Atherosclerosis and Renal Disease in ApoE Null Mice Fed a Western Diet through Reduction of Carbonyl Stress and Inflammation. Br. J. Pharmacol. 2012, 166, 1344-1356. [CrossRef]

67. Menini, S.; Iacobini, C.; Ricci, C.; Fantauzzi, C.B.; Pugliese, G. Protection from Diabetes-Induced Atherosclerosis and Renal Disease by d-Carnosine-Octylester: Effects of Early vs Late Inhibition of Advanced Glycation End-Products in Apoe-Null Mice. Diabetologia 2015, 58, 845-853. [CrossRef] [PubMed]

68. Menini, S.; Iacobini, C.; Fantauzzi, C.B.; Pugliese, G. L-Carnosine and Its Derivatives as New Therapeutic Agents for the Prevention and Treatment of Vascular Complications of Diabetes. Curr. Med. Chem. 2019, 27, 1744-1763. [CrossRef]

69. Forsberg, E.A.; Botusan, I.R.; Wang, J.; Peters, V.; Ansurudeen, I.; Brismar, K.; Catrina, S.B. Carnosine Decreases IGFBP1 Production in Db/Db Mice through Suppression of HIF-1. J. Endocrinol. 2015, 225, 159-167. [CrossRef]

70. Giacco, F.; Du, X.; D’Agati, V.D.; Milne, R.; Sui, G.; Geoffrion, M.; Brownlee, M. Knockdown of Glyoxalase 1 Mimics Diabetic Nephropathy in Nondiabetic Mice. Diabetes 2014, 63, 291-299. [CrossRef] 
71. Berner, A.K.; Brouwers, O.; Pringle, R.; Klaassen, I.; Colhoun, L.; McVicar, C.; Brockbank, S.; Curry, J.W.; Miyata, T.; Brownlee, M.; et al. Protection against Methylglyoxal-Derived AGEs by Regulation of Glyoxalase 1 Prevents Retinal Neuroglial and Vasodegenerative Pathology. Diabetologia 2012, 55, 845-854. [CrossRef] [PubMed]

72. Lee, A.Y.W.; Chung, S.S.M. Contributions of Polyol Pathway to Oxidative Stress in Diabetic Cataract. FASEB J. 1999, 13, 23-30. [CrossRef] [PubMed]

73. Bierhaus, A.; Hofmann, M.A.; Ziegler, R.; Nawroth, P.P. AGEs and Their Interaction with AGE-Receptors in Vascular Disease and Diabetes Mellitus. I. The AGE Concept. Cardiovasc. Res. 1998, 37, 586-600. [CrossRef]

74. Coughlan, M.T.; Thorburn, D.R.; Penfold, S.A.; Laskowski, A.; Harcourt, B.E.; Sourris, K.C.; Tan, A.L.Y.; Fukami, K.; Thallas-Bonke, V.; Nawroth, P.P.; et al. Rage-Induced Cytosolic ROS Promote Mitochondrial Superoxide Generation in Diabetes. J. Am. Soc. Nephrol. 2009, 20, 742-752. [CrossRef] [PubMed]

75. Sourris, K.C.; Morley, A.L.; Koitka, A.; Samuel, P.; Coughlan, M.T.; Penfold, S.A.; Thomas, M.C.; Bierhaus, A.; Nawroth, P.P.; Yamamoto, H.; et al. Receptor for AGEs (RAGE) Blockade May Exert Its Renoprotective Effects in Patients with Diabetic Nephropathy via Induction of the Angiotensin II Type 2 (AT2) Receptor. Diabetologia 2010, 53, 2442-2451. [CrossRef] [PubMed]

76. di Marco, E.; Jha, J.C.; Sharma, A.; Wilkinson-Berka, J.L.; Jandeleit-Dahm, K.A.; de Haan, J.B. Are Reactive Oxygen Species Still the Basis for Diabetic Complications? Clin. Sci. 2015, 129, 199-216. [CrossRef] [PubMed]

77. Iacobini, C.; Vitale, M.; Pesce, C.; Pugliese, G.; Menini, S. Diabetic Complications and Oxidative Stress: A 20-year Voyage Back in Time and Back to the Future. Antioxidants 2021, 10, 727. [CrossRef]

78. Pattison, D.I.; Davies, M.J. Evidence for Rapid Inter- and Intramolecular Chlorine Transfer Reactions of Histamine and Carnosine Chloramines: Implications for the Prevention of Hypochlorous-Acid-Mediated Damage. Biochemistry 2006, 45, 8152-8162. [CrossRef]

79. Boldyrev, A.A.; Aldini, G.; Derave, W. Physiology and Pathophysiology of Carnosine. Physiol. Rev. 2013, 93, 1803-1845. [CrossRef]

80. Scuto, M.; Salinaro, A.T.; Modafferi, S.; Polimeni, A.; Pfeffer, T.; Weigand, T.; Calabrese, V.; Schmitt, C.P.; Peters, V. Carnosine Activates Cellular Stress Response in Podocytes and Reduces Glycative and Lipoperoxidative Stress. Biomedicines 2020, 8, 177. [CrossRef]

81. Farkhondeh, T.; Folgado, S.L.; Pourbagher-Shahri, A.M.; Ashrafizadeh, M.; Samarghandian, S. The Therapeutic Effect of Resveratrol: Focusing on the Nrf2 Signaling Pathway. Biomed. Pharmacother. 2020, 127, 110234. [CrossRef] [PubMed] 